\title{
Biometric indices and population parameters of three polynemid fishes from Batang Lassa Estuary of East Malaysia
}

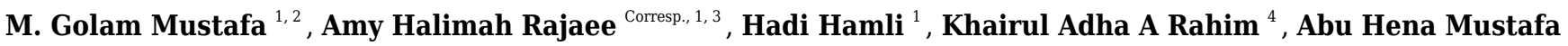 \\ Kamal $^{4}$, Mohd Hanafi Idris ${ }^{4}$ \\ 1 Department of Animal Science and Fishery, Faculty of Agricultural Science and Forestry, Universiti Putra Malaysia Bintulu Sarawak Campus, Bintulu, \\ Sarawak, Malaysia \\ 2 Department of Oceanography, Noakhali Science and Technology University, Noakhali, Bangladesh \\ 3 Institut Ekosains Borneo, Universiti Putra Malaysia Bintulu Sarawak Campus, Bintulu, Sarawak, Malaysia \\ 4 Department of Aquatic Science, Faculty of Resource Science and Technology, Universiti Malaysia Sarawak, Kota Samarahan, Sarawak, Malaysia \\ Corresponding Author: Amy Halimah Rajaee \\ Email address: amyhalimah@upm.edu.my
}

The length-weight relationships (LWRs), condition factor (Kn), growth, mortality and exploitation status of three polynemid fishes, i.e., Filimanus xanthonema (Valenciennes, 1831), Polynemus melanochir (Valenciennes, 1831) and Polynemus paradiseus (Linnaeus, 1758) from Batang Lassa River estuary were estimated. Fish samples were caught during April 2019 to September 2020 using the ESBN (locally called Gnian) having 1.25 to 4.00 $\mathrm{cm}$ mesh size. The total length (TL) and body weight of each individual fish was measured to the nearest $0.1 \mathrm{~cm}$ and $0.01 \mathrm{~g}$ respectively. The growth coefficients $(b)$ for $F$.

xanthonema, P. melanochir and P. paradiseus, were 2.880, 2.717 and 2.724 with the $R^{2}$ values $0.956,0.972$ and 0.936 respectively. Estimated growth coefficients indicated a negative allometric growth pattern for all three threadfin fishes. To date, information regarding length-weight relationships for $F$. xanthonema and $P$. melanochir is insufficient whereas the information is available for $P$. paradiseus. About $40-48 \%$ of fishes exhibited flat or thin body shape $(K n<1), 48-50 \%$ were rounded or fat $(K n>1)$ and only $1-3 \%$ of fishes showed proportional body shape $(K n=1)$. The growth parameters $L_{\infty}, K$ and $\phi^{\prime}$ were estimated at $15.75 \mathrm{~cm}, 0.95 \mathrm{yr}^{-1}$ and 2.37 for $F$. xanthonema; $27.61 \mathrm{~cm} 0.87 \mathrm{yr}^{-1}$ and 2.82 for $P$. melanochir; and $27.30 \mathrm{~cm}, 0.58 \mathrm{yr}^{-1}$ and 2.64 for $P$. paradiseus; respectively. The estimated natural mortality (M) included $2.10,1.69$ and $1.30 \mathrm{yr}^{-1}$; the fishing mortality (F) $0.57,0.67$ and $0.60 \mathrm{yr}^{-1}$; and exploitation ratio (E) $0.21,0.28$ and 0.31 for $F$. xanthonema, $P$. melanochir and $P$. paradiseus respectively. The study concluded that the stocks are still under exploitation ( $\mathrm{E}<0.5$ ) condition. However, the studied Batang Lassa estuary could be a potential nursery ground considering the length at first catch (LC) of $5.0 \mathrm{~cm}, 3.8 \mathrm{~cm}$ and 
$4.0 \mathrm{~cm}$ for $F$. xanthonema, P. melanochir and P. paradiseus and respectively. Therefore, management initiatives are needed to escape juvenile catches. 
1 Biometric indices and population parameters of three

2 polynemid fishes from Batang Lassa Estuary of East

3 Malaysia

M. Golam Mustafa ${ }^{1,4}$, Amy Halimah Rajaee*1,2, Hadi Hamli ${ }^{1}$ and Khairul Adha A Rahim ${ }^{3}$

${ }^{1}$ Department of Animal Science and Fishery, Faculty of Agricultural Science and Forestry,

8 Universiti Putra Malaysia Bintulu Sarawak Campus, Bintulu, Sarawak, Malaysia

9 '2nstitut Ekosains Borneo, Universiti Putra Malaysia Bintulu Sarawak Campus, Bintulu,

10 Sarawak, Malaysia

${ }^{3}$ Department of Aquatic Science, Faculty of Resource Science and Technology, Universiti Malaysia Sarawak, Kota Samarahan, Sarawak, Malaysia

${ }^{4}$ Department of Oceanography, Noakhali Science and Technology University, Noakhali, Bangladesh.

*Corresponding Author: amyhalimah@upm.edu.my

17 18

\section{Abstract}

The Length-weight relationships (LWRs), condition factor (Kn), growth, mortality and exploitation status of three polynemids fishes, i.e., Filimanus xanthonema (Valenciennes, 1831), Polynemus melanochir (Valenciennes, 1831) and Polynemus paradiseus (Linnaeus, 1758) from Batang Lassa River estuary were estimated. Fish samples were caught during April 2019 to September 2020 using the ESBN (locally called Gnian) having 1.25 to $4.00 \mathrm{~cm}$ mesh size. The total length (TL) and body weight of each individual fish was measured to the nearest $0.1 \mathrm{~cm}$ and $0.01 \mathrm{~g}$ respectively. The growth coefficients $(b)$ for $F$. xanthonema, $P$. melanochir and $P$. paradiseus, were $2.880,2.717$ and 2.724 with the $R^{2}$ values $0.956,0.972$ and 0.936 respectively. Estimated growth coefficients inferred the negative-allometric growth pattern for all three threadfin fishes. To date, information regarding length-weight relationships for $F$. xanthonema and. P. melanochir is insufficient whereas the information is available for P. paradiseus. About $40-48 \%$ of fishes exhibited flat or thin body shape $(\mathrm{Kn}<1), 48-50 \%$ were rounded or fat $(\mathrm{Kn}>1)$ and only $1-3 \%$ of fishes showed proportional body shape $(\mathrm{Kn}=1)$. The growth parameters $L_{\infty}, K$ and $\phi$ ' were estimated at $15.75 \mathrm{~cm}, 0.95 \mathrm{yr}^{-1}$ and 2.37 for $F$. xanthonema; 27.61 $\mathrm{cm} 0.87 \mathrm{yr}^{-1}$ and 2.82 for $P$. melanochir; and $27.30 \mathrm{~cm}, 0.58 \mathrm{yr}^{-1}$ and 2.64 for $P$. paradiseus; respectively. The estimated natural mortality (M) included $2.10,1.69$ and $1.30 \mathrm{yr}^{-1}$; the fishing mortality (F) $0.57,0.67$ and $0.60 \mathrm{yr}^{-1}$; and exploitation ratio (E) $0.21,0.28$ and 0.31 for $F$. xanthonema, P. melanochir and $P$. paradiseus respectively. The study concluded that the stocks are still under exploitation $(\mathrm{E}<0.5)$ condition. However, the studied Batang Lassa estuary could be a potential nursery ground considering the length at first catch $(\mathrm{Lc})$ of $5.0 \mathrm{~cm}, 3.8 \mathrm{~cm}$ and 4.0 
39

40

41

42

43

44

45

46

47

48

49

50

51

52

53

54

55

56

57

58

59

60

61

62

63

64

65

66

67

68

69

70

71

72

73

74

75

76

77

78

$\mathrm{cm}$ for F. xanthonema, P. melanochir and P. paradiseus and respectively. Therefore, management initiatives are needed to escape juvenile catches.

\section{Introduction}

Batang Lassa, a deltaic estuary, is situated in the North-West area of Borneo Island, East Malaysia, which meets directly in the South China Sea (Pacific Ocean). The estuary is a dynamic ecosystem which supports multitudes of fish and other aquatic organisms. Malaysia is identified as one of the world's mega diversity centers with 1951 fish species (Chong et al. 2010) where East Malaysia (part of Borneo Island) contributes to a substantial share of fishery resources. Batang Lassa estuary, a part of the outfall of the large catchment river 'Rajang', supports a variety of commercial fishes.

Polynemids are an important fishery resource in Malaysia and in other tropical and sub-tropical regions. The species under the family Polynemidae are commonly known as threadfins.

Filimanus xanthonema (Valenciennes, 1831), a small sized species, commonly known as the yellowthread threadfin is mainly distributed in the eastern part of the Indian ocean and the western part of the Pacific Ocean (Motomura, 2004) which extends toward the Bay of Bengal coast, Indonesia as well as Malaysia including the Borneo Island. Polynemus melanochir (Valenciennes, 1831), commonly known as the blackhand paradise fish, is a medium sized species, distributed from lower Mekong and Borneo Island (East Malaysia and Indonesia) (Motomura, 2004). Polynemus paradiseus (Linnaeus, 1758) or commonly known as paradise threadfin is a medium sized species, with known distribution from the eastern Bay of Bengal and Pacific Ocean coast including Thailand and Indonesia (Motomura, 2004).

Length-weight relationship (LWR) and condition factors are important parameters for fish life and population biometric characteristics. They provide valuable information about the condition factor of fish and the robustness, and are useful for species management and conservation of any ecosystem (Arshad et al., 2012; Lawson, 2011; Yu-Abit, 2011).

Knowledge on the population parameters of fishes is a prerequisite for better planning and management. The primary aspect of stock assessment is to provide guidelines for optimum exploitation of any important aquatic living resources (Sparre \& Venema, 1998). Scientific documents and databases use biological data for fisheries management. However, the availability of data on population parameters is still lacking with respect to many species and geographical variations which leads to data-poor fish stock management of. To date, information on the population dynamics of $P$. paradiseus is available for sub-tropical regions (Nabi et al., 2007, Hossain et al., 2015; Chaklader et al., 2016; Hossain et al., 2017) but not so much on $F$. xanthonema and $P$. melanochir.

There are several studies conducted by different researchers on biometric and population dynamic parameters of different species under polynemidae which included $F$. xanthonema (Feltes, 1991), P. paradiseus (Hossain et al., 2015; Hossain et al., 2017, Islam et al., 1993; Nabi et al., 2007; Nabi et al., 1999;), P. melanochir (Motomura \& Sabaj, 2002), Polydactylus plebeius (Sommer, et al., 1996; Motomura, 2004; Andina et al., 2020), Polydactylus bifurcus 
79 (Motomura, 2004), Polydactylus longipes (Gumanao, et al., 2016), Polynemus aquilonaris

80 (Motomura, 2003), Polynemus dubius (Rainboth, 1996), Polynemus hornadayi (Kottelat, et al., 81 1993), Polynemus kapuasensis (Motomura, 2004), Polynemus multifilis (Motomura, 2004), and

82 Polynemus heptadactylus (Prasad et al., 2005). However, most of the studies were confined 83 mainly on the species records and length information (Tables 1 and 2) and only a few covered 84 LWRs parameters. There is a significant lack of studies on growth and mortality estimation of 85 the polynemid species. Therefore, this study was conducted to estimate the biometric indices and 86 population dynamics for three species under the polynemidae family in the Batang Lassa Estuary 87 of north-western Borneo Island, Sarawak, Malaysia.

88

89

90

91

92

\section{Materials \& Methods}

\section{Study area and sampling}

The research was conducted in Batang Lassa Estuary, a lower part of Rajang Delta, situated in Daro, Sarawak, East-Malaysia. The geographical location of sampling sites lies between $2^{\circ} 53^{\prime} 11.4^{\prime \prime} \mathrm{N} 111^{\circ} 39^{\prime} 26^{\prime \prime} \mathrm{E}$ and $2^{\circ} 68^{\prime} 81.8^{\prime \prime} \mathrm{N} 111^{\circ} 42^{\prime} 33^{\prime \prime} \mathrm{E}$ (Figure 1). Monthly fish samples were collected for 14 months from April 2019 to September 2020 (with the exception of March to June 2020 due to the Covid-19 outbreak; also note that during certain months of the sampling period, species reported in this study were not available in the monthly catch). A total of 12 local fishermen were employed to assist the researchers during sampling. Sampling was carried out using Estuarine Set Bag Net (ESBN) or locally called Gnian with mesh sizes of 1.25 to $4.00 \mathrm{~cm}$ from cod-end to mouth during the full moon period of lunar months, usually 5 to 6 hours per day each month, taking into account the knowledge of local fishermen from previous data (Islam et al. 1993). Considering Gnian (ESBN) is a highly efficient gear among all others for operation in the estuary, due to the high catch and great variation of size in the catch, this special type of stationary net was used following the tidal pattern (high to low tide). Fish specimens were preserved in ice boxes and immediately transferred to the wet laboratory for further analyses. The samples were identified with some standard taxonomic identification keys (Ambak et al., 2010; Froese \& Pauly, 2020; Motomura, 2004). Total length (TL) was measured using a vernier caliper to the nearest $0.1 \mathrm{~cm}$ and total body weight (W) was estimated using a digital electronic balance of $0.01 \mathrm{~g}$ accuracy.

\section{Length-frequency distribution (LFD)}

Length-frequency distribution (LFD) was calculated to get ideas about species-wise population structure. LFDs were constructed by following the standard statistical (Class Interval= (MaxMin) / number of class; number of class $=\sqrt{ }$ ) length-frequency table and using class intervals of $1.0 \mathrm{~cm}, 1.5 \mathrm{~cm}$, and $2.0 \mathrm{~cm}$ for $F$. xanthonema, $P$. melanochir and $P$. paradiseus respectively based on the total individuals.

\section{Estimation of Length-weight relationships and growth pattern}


118 The LWRs of the three studied fishes were done by regression analysis of LW data using the

119

120

121

122

123

124

125

126

127

128

129

130

131

132

133

134

135

136

137

138

139

140

141

142

143

144

145

146

147

148

149

150

151

152

153

154

155

156

power equation by Le Cren (1951): $\mathrm{W}=a^{*} \mathrm{~L}^{\mathrm{b}}$. Where, $\mathrm{W}$ is the fish weight and $\mathrm{L}$ is the total length (TL) of the fish, $a$ is the intercept, and $b$ is the slope of the curve. The power equation was expressed as $\log \mathrm{W}=\log a+b \log \mathrm{L}$ after logarithmic transformation. Outliers were removed from the dataset after fitting Log-log plots of $\mathrm{W}$ and $\mathrm{L}$ data before regression analysis (Froese, 2006). Moreover, coefficient of determination $\left(r^{2}\right)$ was determined to the fit of regression model (Pervaiz et al., 2012).

\section{Estimation of condition factors and body-shape expression}

Relative condition factor $(\mathrm{Kn})$ was estimated for each species using the power equation by Le Cren (1951): $\mathrm{W} / a^{*} \mathrm{~L}^{\mathrm{b}}$. where $\mathrm{W}=$ body-weight and $\mathrm{L}=$ total length of the fish, while $a$ is the intercept and $b$ is the slope of the regression curve of LWR. Body-shape expressions were categorized following Firdaus et al. (2018).

\section{Estimation of Growth parameters - Asymptotic Length $\left(L_{\infty}\right)$ and Growth Coefficient $(K)$}

Von Bertalanffy Growth Function (VBGF) (Von Bertalanffy, 1938; Beverton \& Holt, 1957) was used to estimate the total asymptotic length $\left(L_{\infty} \mathrm{cm}\right)$ and growth coefficient $(K /$ year). The VBGF fitting equation is $L_{t}=L_{\infty}\left(1-\exp \left(-K\left(t-t_{0}\right)\right)\right)$; where $L_{t}=$ length at time $t, L_{\infty}=$ asymptotic length $(\mathrm{cm}), K=$ growth coefficient (/year), $t=$ age of the fish, and $t_{0}=$ age of the fish at zero length.

Monthly length frequency distribution data were constructed to use in VBGF as prerequisite. The ELEFAN I and ELEFAN II routines incorporated in FiSAT software (Gayanilo et al., 2005)

were used to determine $L_{\infty}$ and $K$ values.

\section{Growth performance index ( $\left.\phi^{\prime}\right)$}

Length based growth performance index ( $\left.\phi^{\prime}\right)$ was estimated using the index following Pauly and Munro (1984): $\phi^{\prime}=\log K+2 \log L_{\infty}$.

\section{Mortality Estimation (Total Mortality, Natural Mortality and Fishing Mortality)}

The total mortality (Beverton \& Holt, 1957; Beverton \& Holt, 1966) coefficient, $Z$ (year ${ }^{-1}$ ) was estimated using the length-converted catch curve by means of the final estimates $L_{\infty}$ and $K$ and the length frequency distribution data. The natural mortality $M$ (year ${ }^{-1}$ ) was estimated using Pauly's empirical equation as he suggested that this method gives a reasonable of ' $M$ ' (Pauly, 1980): $\log _{10} M=-0.0066-0.279 \log _{10} L_{\infty}+0.06543 \log _{10} K+.04634 \log _{10} T$. Mean annual water temperature (T) was set at $29^{\circ} \mathrm{C}$ following the mean annual water temperature of the study area during sample collection. Fishing mortality rate $F$ (year ${ }^{-1}$ ) was obtained by $F=Z-M$ (Silvestre \& Garces, 2004).

\section{Estimation of exploitation ratio (E)}

The exploitation ratio, $E$, was calculated by the following formula, $E=F /(F+M)$ (Beverton \& Holt, 1966; Gulland, 1971). According to Gullen (1983), the limit reference point (LRP) of E 
157 was followed as $\mathrm{E}=0.5$ for optimum exploitation where $\mathrm{E}>0.5$ and $\mathrm{E}<0.5$ indicate over

158

159

160

161

162

163

164

165

166

167

168

169

170

171

172

173

174

175

176

177

178

179

180

181

182

183

184

185

186

187

188

189

190

191

192

193

194

195

196

exploitation and under exploitation respectively.

\section{Probability of Capture}

Calculation of probability of capture was made from the length-converted catch curve. The values of $L_{25}, L_{50}$ and $L_{75}$ were extracted from the catch curve which implied that $25 \%, 50 \%$ and $75 \%$ of the fish will be vulnerable to the gear (Pauly, 1984).

\section{Recruitment Pattern}

The backward projection of the frequencies onto the time axis of a time-series of samples along a trajectory defined by the Von Bertalanffy growth equation were applied to obtain recruitment patterns. This is a routine that reconstructs the recruitment pulses from a time series of lengthfrequency data to determine the number of pulses per year and the relative strength of each pulse (Gayanilo et al., 2005).

All the population dynamics parameters were analyzed using the FiSAT-II software package (FAO-ICLARM Stock Assessment Tools).

\section{Results}

\section{Length-frequency distribution}

The catch composition of three polynemid fishes of Batang Lassa estuary revealed that they were available throughout the year. However, the frequencies of Filimanus xanthonema (both monthly and total catch) were lower than the other two species (supplementary data sheet). The lengthbased composition and frequency distribution of three species are presented in Table 3 and Figure 2. A total of 579 sorted and qualified individuals $(111 \mathrm{~F}$. xanthonema, 165 P. melanochir and 303 P. paradiseus) were measured for this study. The total lengths (TL) throughout the sampling period ranged from 4.5 to $13.5,4.5$ to 26.0 and 3.6 to $31.5 \mathrm{~cm}$ for $F$. xanthonema, $P$. melanochir and $P$. paradiseus respectively. A new information of total length (TL) for $P$. paradiseus was recorded at $31.5 \mathrm{~cm}$ when compared with the fishbase online data and other scientific literatures (Froese \& Pauly, 2020). The predicted extreme lengths with the ranges of $95 \%$ confident interval are presented in Table 3 and Figure 3.

\section{Length-weight relationship (LWRs) and growth pattern}

The estimated relative growth coefficients $(b)$ for $F$. xanthonema, $P$. melanochir and $P$. paradiseus were 2.880, 2.82 and 2.87 with the adjusted $R^{2}$ value of $0.956,0.970$ and 0.981 respectively which indicated the negative allometric growths of the studied fishes. The summarized data and descriptive statistics including regression parameters ( $a$ and $b$ ) of LWRs for studied species are given in Table 4. The LWRs curves with regression equations are shown in Figure 4. 


\section{Condition factors and body shape expression}

198 The calculated average relative condition factors $(\mathrm{Kn})$ across the study varied from 1.01 to 1.02.

199 The minimum, maximum and mean values of Kn were $0.56,0.63 \& 0.52 ; 1.48,1.93 \& 1.55$ and

$2001.02,1.02 \& 1.01$ for $F$. xanthonema, P. melanochir and $P$. paradiseus respectively. For body

201 shape expression based on the condition factors classification, it is observed that $40-48 \%$ of

202 fishes exhibited flat or thin shape $(\mathrm{Kn}<1), 48-50 \%$ exhibited rounded or fat $(\mathrm{Kn}>1)$ and only 1 -

$2033 \%$ fishes showed proportional body shape $(\mathrm{Kn}=1)$. The details of condition factors and body

204 shape types of the three studied species are presented in Table 5 and Figure 5.

205

206

\section{Growth parameters}

207 For growth parameters, the asymptotic lengths $\left(L_{\infty}\right)$ were $15.75 \mathrm{~cm}, 27.61 \mathrm{~cm}$ and $27.30 \mathrm{~cm}$ for

208 F. xanthonema $P$. melanochir and $P$. paradiseus respectively. The estimated growth coefficients

$209(K)$ were $0.95,0.87$ and 0.58 year $^{-1}$ respectively, while the calculated growth performance

210 indices $(\phi ')$ were $2.37,2.82$ and 2.64 respectively for the same species mentioned. The growth

211 curves on restructured length-frequency distribution are presented in Figure 6 and the estimated

212 growth parameters are shown in Table 6.

213

214 Mortality and exploitation parameters

215 The values of natural mortality (M) were 2.10, 1.69 and 1.30 year $^{-1}$ respectively for $F$.

216 xanthonema, $P$. melanochir and $P$. paradiseus. The fishing mortality $(\mathrm{F})$ values were $0.57,0.67$

217 and 0.60 year $^{-1}$; hence, the total mortality $(Z)$ were computed as 2.67, 2.37 and 1.90 for $F$.

218 xanthonema, $P$. melanochir and $P$. paradiseus respectively. The exploitation ratios (E) were

$2190.21,0.28$ and 0.31 for the mentioned fishes respectively. Figure 7 represents the length

220 converted catch curves utilized for estimation of mortality parameters M, F \& Z, and exploitation

221 ratio (E) for the three polynemid fishes from Batang Lassa Estuary.

222

223

224

225

226

227

\section{Probability of capture, recruitment pattern and Yield-per-recruit}

Probable lengths of first capture (Lc) were found to be $5.0 \mathrm{~cm}, 3.8$ and $4.0 \mathrm{~cm}$ for $F$. xanthonema, $P$. melanochir and $P$. paradiseus respectively. Estimated length sizes for $25 \%\left(L_{25}\right)$, $50 \%\left(L_{50}\right)$ and $75 \%\left(L_{75}\right)$ probability of capture were $8.13 \mathrm{~cm}, 8.99 \mathrm{~cm}$ and $9.82 \mathrm{~cm}$ for $F$. xanthonema; $12.02 \mathrm{~cm}, 15.19 \mathrm{~cm}$ and $17.12 \mathrm{~cm}$ for $P$. melanochir and $16.34 \mathrm{~cm}, 18.14 \mathrm{~cm}$ and

228 $19.87 \mathrm{~cm}$ for $P$. paradiseus respectively. Probabilities of capture of three polynemid fishes are presented in Figure 8. The yield-per-recruit values by knife edge procedure were 0.232, 0.24 and 02.34 at $\mathrm{E}_{50}$ and $0.361,0.369$ and 0.362 at $\mathrm{E}_{\max }$ for $F$. xanthonema, P. melanochir and $P$.

231 paradiseus respectively (Figure 9). All three of the studied species showed round the year

232 recruitment with a single peak for $F$. xanthonema, $P$. paradiseus and probable double peak for 233 P. melanochir (Figure 10).

234

235

\section{Discussion}

\section{Length-frequency distribution}


237 Feltes (1991) reported a maximum total length of $14 \mathrm{~cm}$ for $F$. xanthonema which was close to 238 the present finding $(13.5 \mathrm{~cm})$. The maximum TL of $P$. melanochir recorded from this study was $23926 \mathrm{~cm}$ which was higher than the recorded maximum TL of $20 \mathrm{~cm}$ by Motomura and Sabaj 240 (2002). Since available records for F. xanthonema and P. melanochir are quite limited in the 241 literature, findings from this study will surely contribute to the current records.

242 On the other hand, the maximum total length of $P$. paradiseus varied from $13.7 \mathrm{~cm}$ (Chaklader et 243 al., 2016) to $22.5 \mathrm{~cm}$ (Nabi et al., 1999) which suggested that the record of TL from this study is 244 a new maximum $(31.5 \mathrm{~cm})$ compared to other records from the fishbase online data and other 245 scientific literatures (Froese \& Pauly, 2020). The accumulated length-frequency data exhibited 246 from this study showed that about $9.87 \%, 22.44 \%$ and $8.72 \%$ of fishes were within the maximum-length-ranges group for $F$. xanthonema, $P$. melanochir and $P$. paradiseus

248 respectively. Overall, the present study implies a good situation to reach maximum length 249 compared with all available records.

250

\section{Length-weight relationship (LWRs) and growth pattern}

252

253

254 The estimated relative growth coefficients $(b)$ for all three species indicated slightly negative allometric growth that may be inclined toward the isometric nature as the catch was very selective i.e. ESBN (Gnian) which caught under-sized fishes. Chaklader et al. (2016) reported similar findings for $P$. paradiseus caught in the coastal waters of Bangladesh which reported a $b$ value of 2.80. Nabi et al. (2017) also reported negative allometric growth with a $b$ value of 2.740 for $P$. paradiseus from the estuarine set bag net fishery of Bangladesh. On the other hand, study on $P$. paradiseus from Hooghly-Matlah estuary, West Bengal reported isometric growth with a $b$ value of 3.120 (Mandal et al., 1998), $b$ value of 3.120 (Nath et al., 2004) and $b$ values of 3.115 and 3.182 for juvenile and adult groups respectively (Borah et al., 2020). Nabi et al. (1999) reported positive allometry with $b$ values of 3.389 and 3.512 for male and female respectively from the Bay of Bengal in Bangladesh, followed by Hossain et al. (2015) who reported a $b$ value of 3.23 from Tetulia river, Southern Bangladesh. Hossen et al. (2017) reported a negative allometric growth for monsoon $(b=2.737)$ but isometric growth for pre-monsoon $(b=3.032)$ and post-monsoon catch $(b=0.35)$. Differences of growth pattern for the same species are not something new since the $b$ value can be influenced by many factors such as maturity, sex, seasonal effect, food and feeding habit among others (Bagenal et al., 1978; Hossain et al., 2012).

\section{Condition factors and body shape expression}

278 Chaklader et al. (2016) reported that the relative condition factors of $P$. paradiseus varied from

2791.80 to 2.23 i.e. very flat and rounded body shapes which were higher than the present findings 280 (1.01-1.02). On the contrary, relative condition factor for the same species varied from 0.87 to 
281

282

283

284

285

286

287

288

289

290

291

292

293

294

295

296

297

298

299

300

301

302

303

304

305

306

307

308

309

310

311

312

313

314

315

316

317

318

319

320

1.31 as estimated by Hossen et al. (2017) which were roughly similar with our results. Borah et al. (2020) also reported $\mathrm{Kn}$ values of 1.10 for females and 1.05 for males of $P$. paradiseus. It was suggested that $\mathrm{Kn}$ values of more than 1 indicate good general condition of the fish and less than 1 denote the opposite condition (Le Cren, 1951).

The average $\mathrm{Kn}$ was around the proportional nature $(\mathrm{Kn}=1.0)$ shaped which implied that the species were not thin or fat shaped. It could be mentioned here that the Kn values followed almost the similar pattern of LWRs growth co-efficient (b) i.e. slightly negative allometric growth. Further, it may have relation with under-sized catch by the selective gear (ESBN/Gnian). Following the body shape classification based on condition factor by Firdaus et al. (2018), this present study observed about $40-48 \%$ of fishes under 'flat or thin' shape $(\mathrm{Kn}<1), 48-50 \%$ under 'rounded or fat' $(\mathrm{Kn}>1)$ and only $1-3 \%$ fishes showed 'proportional' body shape $(\mathrm{Kn}=1)$. Although there is limitation of such information, it can be assumed that the present body shape indices of the three polynemid fishes were at both sides of the proportional nature. This study did not cover the ecosystem effects, e.g. natural food availability, predator-prey relation, and migration pattern of the Batang Lassa estuary. Therefore, future research should take attempt to find the relations of the ecosystem effects on the growth pattern and body indices.

\section{Growth parameters}

The growth parameters (asymptotic length $L_{\infty}$, growth performance indices $\phi$ ' and growth coefficients $K$ ) of fish population dynamics are fundamental toward fisheries assessment and management. Some reported $L_{\infty}$ for P. paradiseus were $20.48 \mathrm{~cm}$ (Nabi et al., 2007) and 21.30 $\mathrm{cm}$ (Islam et al.,1993) in the northern Bay of Bengal which were shorter than the present findings. However, Prasad et al. (2005) reported $L_{\infty}$ of $38.4 \mathrm{~cm}$ for a related species $(P$. heptadactylus) in Mumbai coast, Arabian sea. These variations were due to stock differences in spatial scale. The present growth coefficients $(K)$ were $0.95,0.87$ and 0.58 year $^{-1}$ for $F$. xanthonema, P. melanochir and P. paradiseus respectively. Sparre and Venema (1998) suggested that growth coefficients $K=1.0$ year $^{-1}$ is fast growth, $K=0.5$ year $^{-1}$ is medium growth and $K=0.2$ year $^{-1}$ is slow growth, suggesting all three species reported in this study are within the medium-fast growth rate category. The estimated growth coefficients are a little higher for $P$. paradiseus compared with studies by Nabi et al. (2007) which was 0.48 year $^{-1}$ and 0.52 year${ }^{1}$ (Islam et al.,1993). However, Prasad et al. (2005) reported $K$ value of 0.82 year $^{-1}$ for $P$. heptadactylus and 0.64 year $^{-1}$ (Andina et al., 2020) for Polydactylus plebeius which are consistent with the present findings. Variations of $L_{\infty}$ and $K$ within the same species can be a result of several factors such as variances of water parameters, food resources, the rate of metabolism, and pollution (Sparre \& Venema, 1998).

To our knowledge, there is no report on growth for F. xanthonema and P. melanochir, though the $K$ values of pelagic fishes are generally higher. Length-based estimation of growth coefficient $(K)$ using ELEFAN showed a higher rate while the LWRs coefficient (b) was based on actual data of length and weight which showed a slightly negative allometric growth. Both parameters $(K$ and $b$ ) justified that these might be linked with immature catch from the stock. However, the 
321 Batang Lassa could be a potential nursery habitat for the species due to its higher growth co-

322

323

324

325

326

327

328

329

330

331

332

333

334

335

336

337

338

339

340

341

342

343

344

345

346

347

348

349

350

351

352

353

354

355

356

357

358

359

360

efficient (Mustafa et al., 2019). As for the growth performance indices ( $\left.\phi^{\prime}\right)$, comparison with other polynemid species was 2.745 (Wehye \& Amponsah, 2017), 2.741 (Sossoukpe et al., 2017) and 2.85 (Konan et al., 2012) for Galeoides decadactylus and 3.06 for Polydactylus quadrifilis (Bedia et al., 2020). Findings from this study were 2.37, 2.82 and 2.64 for $F$. xanthonema, P. melanochir and $P$. paradiseus respectively, suggesting a moderate growth performance. Abowei (2010) suggested that a high-performance index is attributed to the ability of the fish survival strategies in order to avoid predators by growing rapidly and reducing risk of becoming prey.

\section{Mortality and exploitation parameters}

Fishing mortality (F), natural mortality (M) and exploitation level (E) denote the indication of overfishing status of a stock (Mustafa et al., 2014). Values of M and F were reported as 1.21 and 3.17 (Nabi et al., 2007) for P. paradiseus which is in contrast with the present finding ( $\mathrm{M}=1.30$ year $^{-1} ; \mathrm{F}=0.60$ year $^{-1}$ ) for the same species. This nature of mortality might have relation with the high fishing pressure in the Bangladesh coast. To date, no reports of mortality parameters are available for F. xanthonema and P. melanochir. However, the $\mathrm{M}$ and $\mathrm{F}$ values reported as 1.17 and 1.59 (Andina et al., 2020) for another polynemid (Polydactylus plebeius) were relatively closer to the present findings. On the other hand, the estimated exploitation ratios (E) were 0.21 , 0.28 and 0.31 for $F$. xanthonema, $P$. melanochir and $P$. paradiseus respectively. As the exploitation rate was lower than the optimum fishing level (0.5), this indicates low fishing pressure for all three species for the current ESBN fishery at Batang Lassa. Nabi et al. (2007) reported $\mathrm{E}$ as 0.72 for $P$. paradiseus which indicates high overfishing and hence agreed with the fisher fishing mortality (F) value. Andina et al. (2020) reported E as 0.58 for Polydactylus plebeius and 0.74 for Polynemus heptadactylus (Prasad et al., 2005) which are also higher than the optimum level $(\mathrm{E}=0.5)$. Although we have no reports for F. xanthonema and P. melanochir, there is a clear indication of under exploitation $(\mathrm{E}<0.5)$ for all three studied fish stocks.

The notable feature of the mortality characteristic is that the natural mortalities are higher in all cases of the studied species. There might be multiple reasons behind this. The strongest reason could be due to very low fishing pressure based on field observation and number of fishermen in the sampling area (total 45 including 12 fulltime and 33 part-time). The other possible reasons like food availability, predation nature and migration process are subjected to further studies.

\section{Probability of capture, recruitment pattern and yield-per-recruit}

Probability of capture at different length group of any stock is an important parameter for fish stock management. Length of first capture (Lc) of $P$. paradiseus was $4 \mathrm{~cm}$ which is combatively larger than reported by Nabi et al. (2007) which recorded $0.30 \mathrm{~cm}$ for the same species using ESBN, indicating severely juvenile catch in that coast. Data from the present finding is still rather threatening, showing indication of lower size $(4 \mathrm{~cm})$ for $P$. paradiseus. Though there are no recorded data for other species, it seemed both showed undersized first catch i.e. $5.0 \mathrm{~cm}$ and

Peer) reviewing PDF | (2021:03:59171:3:0:REVIEW 18 Aug 2021) 
361

362

363

364

365

366

367

368

369

370

371

372

373

374

375

376

377

378

379

380

381

382

383

384

385

386

387

388

389

390

391

392

393

394

395

396

397

398

399

$3.8 \mathrm{~cm}$ for $F$. xanthonema, $P$. melanochir respectively which reflected some juvenile catch related to nursery habitat of the species and the gear (Gnian) used. Estimated capture at different length size implies $F$. xanthonema and $P$. paradiseus could reach maximum size $\left(L_{75}\right)$ compared to $P$. melanochir. This nature of catch may link with high commercial demand of the species P. melanochir.

The yield-per-recruit by knife edge procedure were found to be $0.232,0.240 \& 0.234$ at $\mathrm{E}_{50}$ and $0.361,0.369 \& 0.362$ at $\mathrm{E}_{\max }$ for $F$. xanthonema, P. melanochir and P. paradiseus respectively. All three studied species showed round the year recruitment with a single peak for $F$. xanthonema and P. paradiseus with probable double peak for P. melanochir. Nabi et al. (2007) also reported a double peaked pattern of recruitment of $P$. paradiseus in the Bangladesh coast. As $P$. melanochir might have affiliation with $P$. paradiseus since both are under the same genus with very little morphological variations, $F$. xanthonema somehow is a different small sized fish having a single peak of recruitment. However, further study is needed to confirm this feature in different stocks of a different ecosystem.

\section{Conclusions}

The studied three polynemid species are commercially important food fishes. The estimated population parameters could be used to assess the stock of Batang Lassa estuary for future management. The present study revealed that the studied fishes exhibited relatively higher growth rate and the stock is under exploited. However, some level of recruitment overfishing was observed in the case of $P$. melanochir and $P$. paradiseus. This might be occurring due to gear selectivity (Gnian). The features of natural mortality and growth patterns are generally related to the ecosystem with the behavior of the species and the fishing pressure as well. Therefore, further research should address issues like food habit, predation-prey and the migration nature of the ecosystem for these species. Overall, the study reveals that the population of three polynemid fishes met the sustainable level in Batang Lassa estuary. Finally, the biometric and population information of this study are relatively new and shall contribute toward future research works on aquatic resource management and conservation.

\section{Acknowledgements}

This study is part of a $\mathrm{PhD}$ work of the first author. The authors wish to acknowledge the Ministry of Higher Education, Malaysia for providing research grant under the Fundamental Research Grant Scheme (FRGS/1/2019/WAB09/UPM/02/2; Project no. 07-01-19-2209FR).

\section{References}

Abowei JFN. 2010. Some population parameters of Distichodus rostratus (Gunther, 1864) from the fresh water reaches of lower Nun river, Niger Delta, Nigeria. Advance Journal of Food Science and Technology, 2(2): 84-90

Ambak MA, Isa M, Zakaria Z, Ghaffar MA. 2010. Fishes of Malaysia, 1st ed. (p. 334).

Malaysia:Penerbit Universiti Malaysia Terengganu, ISBN: 9789675366260.

Peerj reviewing PDF | (2021:03:59171:3:0:REVIEW 18 Aug 2021) 
400

401

402

403

404

405

406

407

408

409

410

411

412

413

414

415

416

417

418

419

420

421

422

423

424

425

426

427

428

429

430

431

432

433

434

435

436

437

Andina RP, Reza A, Prihatiningsih. 2020. Biological aspect and exploitation status of striped threadfin fish (Polydactylus plebeius Broussonet, 1782) in Merauke waters and its surrounding, Papua Province, Indonesia. AACL Bioflux, 13 (3). 1308-1319.

Arshad A, Amin SMN, Nuradiella YLZ. 2012. Population characteristics of A. japonicus from Kedah coastal waters of Peninsular Malaysia. Journal of fisheries and aquatic sciences, 7(2), 162-172.

Bagenal TB, Tesch FW. 1978. Age and growth, In: Bagenal TB (Ed.) Methods for the assessment of fish production in freshwater. Oxford, Blackwell Scientific Publication, pp. 101-136.

Bedia TA, Coulibaly B, Konan YA, Kouamelan EP, N'douba V. (2020). Growth pattern, mortality and exploitation rate of the Giant African threadfin, Polydactylus quadrifilis (Cuvier, 1829) from Ebrié Lagoon (Potou Sector, Côte d'Ivoire). Asian Journal of Fisheries and Aquatic Research, 9(2):33-42.

Beverton RJH, Holt SJ. 1966. Manual of Methods for Fish Stock Assessment, Part 2; Tables of Yield Functions, Fisheries Technical Paper No. 38, Rome, Italy: Food and Agricultural Organization of the United Nations.

Beverton RJH, Holt SJ. 1957. On the Dynamics of Exploited Fish Populations. Fish. Invest. Ser. II; 19: 5 - 33.

Borah N, Das SK, Bhakta D. 2020. Length-weight relationship and relative condition factor of Polynemus paradiseus (Linnaeus, 1758) from Hooghly-Matlah estuary, West Bengal. Journal of The Inland Fisheries Society of India, 52(2): 204-209.

Chaklader MR, Siddik MAB, Ashfaqun N. 2016. Morphometric Parameters and Allometric Growth in Paradise Threadfin Polynemus paradiseus (Linnaeus, 1758) from a Coastal Rover of Bangladesh. J Aquac Res Development. 7(3): 1-5.

Chong VC, Lee PKY, Lau CM. 2010. Diversity, extinction risk and conservation o Malaysian fishes. Journal of Biology, 76: 2009-2066.

Correia E, Granadeiro JP, Regalla A. 2018. Length-weight relationship of fish species from the Bijagos Archipelago Guinea-Bissau. Journal of Applied Ichthyology, 34(1): 177-179. DOI: $\underline{10.1111 / j a i .13522}$

Feltes RM. 1991. Revision of the polynemid fish genus Filimanus, with the description of two new species. Copeia 1991:302-322

Firdaus M, Lelono RD, Saleh R. 2018. The expression of the body shape in fish species Hapadon nehereus (Hamilton, 1822) in the waters of Juata Laut, Tarakan city, North Kalimantan. ACCL Bioflux. 11(3): 613-623.

Froese R. 2006. Cube law, condition factor and weight-length relationships: history, metaanalysis and recommendations. Journal of Applied Ichthyology 22, 241-253.

Froese, R. \& Pauly, D. (2020). FishBase. World Wide Web electronic publication. Retrieved from http://www.fishbase.org. 
438 Gayanilo FC, Sparre P, Pauly D. 2005. FAO-ICLARM Stock Assessment Tools II (FiSAT II), 439 User's Guide, Computerized Information Series (Fisheries) No. 8, (Revised Version), Food

440

441

442

443

444

445

446

447

448

449

450

451

452

453

454

455

456

457

458

459

460

461

462

463

464

465

466

467

468

469

470

471

472

473

474

475 and Agriculture Organization of the United Nations, Rome, Italy.

Gulland JA. 1983. Fish Stock Assessment: A Manual of Basic Method. New York: Wiley and Sons Inter-science. Volume 1, FAO/Wiley Series on Food and Agricultural. p. 233.

Gulland JA. 1971. The Fish Resources of the Ocean, London, UK: Fishing News (Books) Ltd.

Gumanao GS, Saceda-Cardoza MM, Mueller B. 2016. Length-weight and length-length relationships of 139 Indo-Pacific fish species (Teleostei) from the Davao Gulf, Philippines. $J$. Appl. Ichthyol. 33(2):377-385. DOI: http://dx.doi.org/10.1111/jai.12993

Hossain MY, Rahman MM, Fulanda B, Jewel MAS, Ahamed F, Ohtomi J. 2012. Length-weight and length-length relationships of five threatened fished from the Jamuna (Brahmaputra River distributary) River, northern Bangladesh. J. Appl. Ichthyol. 28: 275-277.

Hossain MY, Sayed SRM, Rahman MM. 2015. Length-weight relationships of nine fish species from the Tetulia River, southern Bangladesh. J. Appl. Ichthyol. 1-3. Doi: 10.1111/jai.12823

Hossen MA, Hossain MY, Ali MM. 2017. Seasonal variations of growth pattern and condition of Paradise threadfin Polynemus paradiseus (Polynemidae) from Tetulia River in Southern Bangladesh. Indian Journal of Geo Marine Science. 46(3): 582-590.

Islam MS, Khan MG, Quayum SA. 1993. Estuarine set bag net fishery of Bangladesh. In: Studies of Interactive Marine fisheries of Bangladesh, BOBP (Bay of Bengal Program) Working Paper No 89, Madras, India.

Konan KS, Diaby M, Agnissan A, JP, Kone A, N'daK. 2012. Croissance et âge des poisons capitaines: Polydactylus quadrifilis (Cuvier, 1829), Galeoides decadactylus (Bloch, 1795) et Pentanemus quinquarius (Linné, 1758) de la pêcherie artisanale maritime de GrandLahou (Côte d'Ivoire), Int. J. Biol. Chem. Sci, 6: 1112-1127.

Kottelat M, Whitten AJ, Kartikasari SN. 1993. Freshwater fishes of Western Indonesia and Sulawesi. Periplus Editions, Hong Kong. 221 p.

Lawson EO. 2011. Length-weight relationships and fecundity estimates in mudskipper, Periophthalmus papilio (Bloch and Schneider 1801) caught from the mangrove swamps of Lagos Lagoon, Nigeria. Journal of Fisheries and Aquatic Sciences, 6: 264-271.

Le Cren ED. 1951. The length-weight relationship and seasonal cycle in gonad weight and condition in the perch (Perca fluviatilis). Journal of Animal Ecology 20(2): 201-219. https://doi.org/10.2307/1540

Mandal, SK, Mitra PM, Gupta, RA. 1998. Population dynamics and stock assessment of Polynemus paradiseus of the Hoogly-Matlah estuarine system. Journal of the Inland Fisheries Society of India, 30(2): 19-23.

Motomura H. 2004. Threadfins of the world (Family Polynemidae). An annotated and illustrated catalogue of polynemid species known to date. FAO Spec. Cat. Fish. Purp. Rome: FAO. 3:117 p. 
476

477

478

479

480

481

482

483

484

485

486

487

488

489

490

491

492

493

494

495

496

497

498

499

500

501

502

503

504

505

506

507

508

509

510

511

512

513

514

515

Motomura H. 2003. A new species of freshwater threadfin, Polynemus aquilonaris, from Indochina, and redescription of Polynemus dubius Bleeker, 1853 (Perciformes: Polynemidae). Ichthyol. Res. 50(2):154-163.

Motomura H, Kullander SO, Yoshino T. 2002. Review of seven-spined Polynemus species (Perciformes: Polynemidae) with designation of a neotype for P. paradiseus Linnaeus, 1758. Ichthyol. Res., 49(4): 307-317.

Motomura H, Sabaj MH. 2002. A new subspecies, Polynemus melanochir dulcis, from Tonle Sap Lake, Cambodia, and redescription of P. m. melanochir Valenciennes in Cuvier and Valenciennes, 1831 with designation of a neotype. Ichthyol. Res., 49(2): 181-190.

Mustafa MG, Ahmed I, Ilyas M. 2019. Population Dynamics of Five Fish Species in the Sundarbans Ecosystem of Bangladesh: Recent Advancement. Journal of Applied Life Science. 22(2): 1-13.

Mustafa MG, Sinha S, Islam R, Mallick N. 2014. Population dynamics of Notopterus notopterus (Pallas, 1769) from the Kaptai reservoir of Bangladesh. SAARC Journal of Agriculture. 12(2): 112-122.

Nabi MRN, Hoque MA, Rahman RA. 2007. Population Dynamics of Polynemus paradiseus from Estuarine Set Bag Net Fishery of Bangladesh. Chiang Mai Journal of Science. 34(3): 355-368.

Nabi MR, Kader MA, Hakim MA. 1999. Length-weight relationship and condition factor in the fish Polynemus paradiseus from the Bay of Bengal. The Chittagong University Journal of Science, 23(2): 87 - 91.Nath, D. Misra, RN, Karmakar, HC. 2004. The Hoogly estuarine system: Ecological flux, fishery resources and production potential. ICAR-Central Inland Fisheries Research Institute Bull. No 130, 79p.

Pauly D. 1980. On the Interrelationships between Natural Mortality, Growth Parameters and Mean Environmental Temperature in 175 Fish Stocks, J. Cons. Ciem. 39(2):175-192.

Pauly D, Munro JL. 1984. Once more on the comparison of growth in fish and invertebrates. ICLARM: International Center for Living Aquatic Resources Management, Fishbyte, 2(1): p. 21.

Pervaiz K, Iqbal Z, Mirza MR. 2012. Length-weight, length-length relationships and feeding habits of wild Indus Mahseer, Tor macrolepis, from Attock. Pakistan. Journal of Applied Ichthyology, 28(4), 673-676. https://doi.org/10.1111/j.1439-0426.2012.01953.x

Prasad RR, Jaiswar AK, Reddy SB. 2005. Growth, mortality and yield per recruit of Polynemus heptadactylus (Cuvier) (Teleostei: Polynemidae) from Mumbai waters, India. Fisheries Research. 76(1): 155-161. DOI:10.1016/j.fishres.2005.06.009

Rainboth WJ. 1996. Fishes of the Cambodian Mekong. FAO species identification field guide for fishery purposes. FAO, Rome, $265 \mathrm{p}$.

Silvestre GT, Garces LR. 2004. Population Parameters and Exploitation Rate of Demersal Fishes in Brunei Darussalam (1989-1990). Fish. Res. 69: 73-90.

Sommer C, Schneider W, Poutiers JM. 1996. FAO species identification field guide for fishery purposes. The living marine resources of Somalia. FAO, Rome. 376 p. 
516 Sossoukpe E, Imorou RS, Adite A, Fiogbe ED. 2016. Growth, mortality and exploitation of the 517 African lesser threadfin Galeoides decadactylus (Pisces, Polynemidae) fishing by the gill net 518 'soovi' in Benin nearshore waters. Journal of FisheriesSciences. 10(3):31-37.

519 Sparre PJ, Venema SC. 1998. Introduction to Tropical Fish Stock Assessment part I: Manual 520 FAO Tech Pap No. 306/Rev 2 Rome FAO, p-407

521 Vidthayanon C, Termvidchakorn A, Pe M. 2005. Inland fishes of Myanmar. Southeast Asian 522 Fisheries Development Center, $160 \mathrm{pp}$.

523 VonBertalanffy L. 1938. A Quantitative Theory of Organic Growth. Hum. Biol.; 10: 181-213. 524 Wehye A, Amponsah S. 2017. Growth, mortality and exploitation rates of Lesser African 525 threadfin, Galeoides decadactylus (Bloch,1795) within the coastal waters of Liberia.

526 International Journal of Fisheries and Aquatic Research, 2(2): 43-49.

527 Yu-Abit IL. 2011. Length-weight relationship and condition factor of three dominant species 528 from the lake Tasik Kenyir, Terengganu, Malaysia. Journal of Fisheries and Aquatic Sciences, 529 6(7), 852-856. 
Figure 1

Sampling stations of studied threadfin fishes at the Batang Lassa Estuary of South China Sea, Sarawak, Malaysia

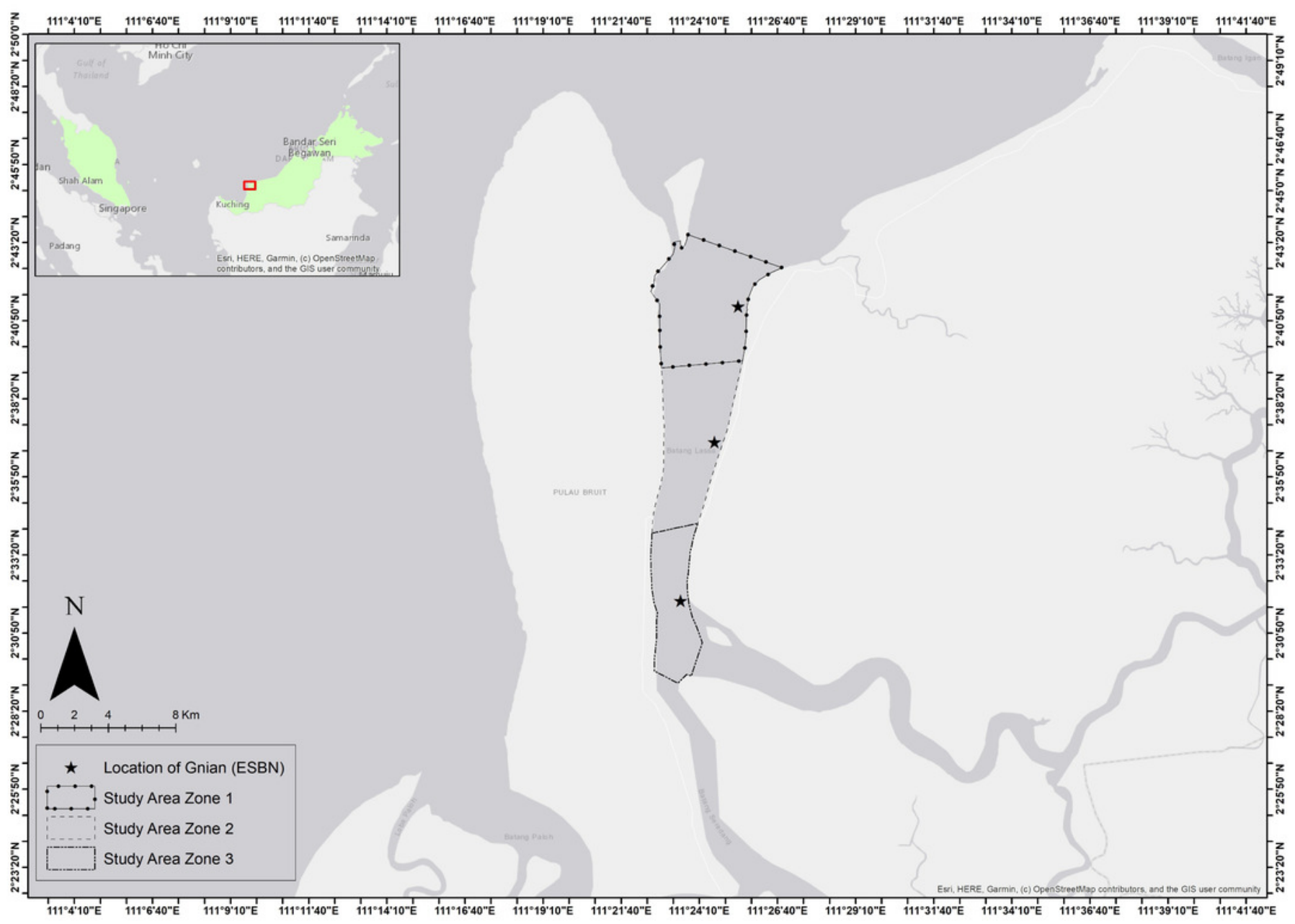


Figure 2

Figure 2 Length-frequency distribution of three polynemids - (A) Filimanus xanthonema (B) Polynemus melanochir and (C) Polynemus paradiseus

(A)

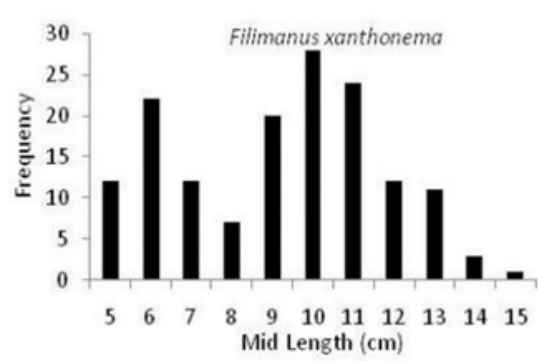

(B)

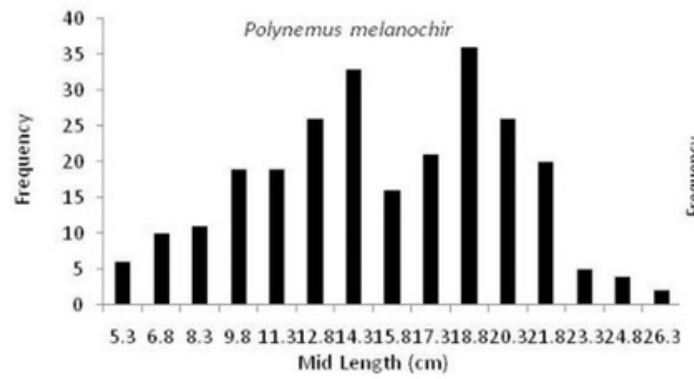

(C)

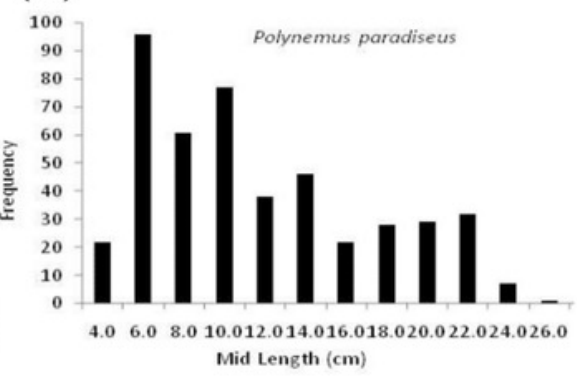


Figure 3

Predicted extreme-length probability of three polynemids - (A) Filimanus xanthonema (B) Polynemus melanochir and (C) Polynemus paradiseus

Maximum observed length (black dots), trend lines (black lines), maximum predicted length (blue-dotted range based on samples) and probability plot with corresponding confidence region (95\% probability, redlines).

(A)

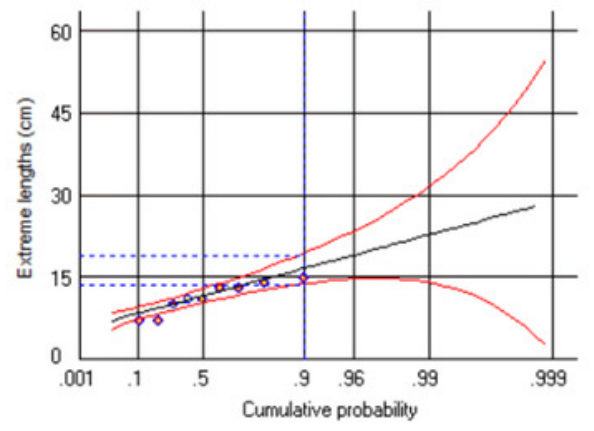

(B)

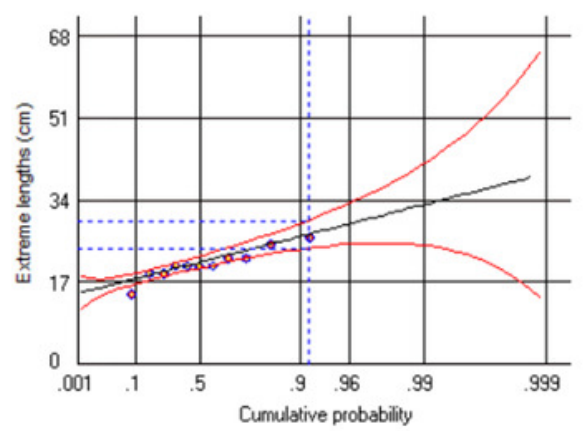

(C)

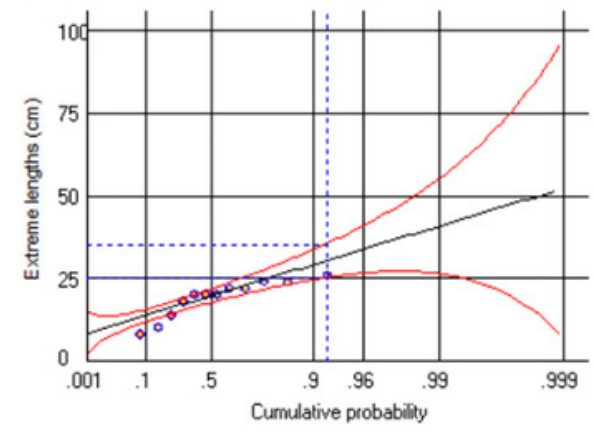


Figure 4

Length-weight relationships (parabolic and logarithmic) of three polynemids - Filimanus xanthonema, Polynemus melanochir and Polynemus paradiseus 


\section{Parabolic LWRs}
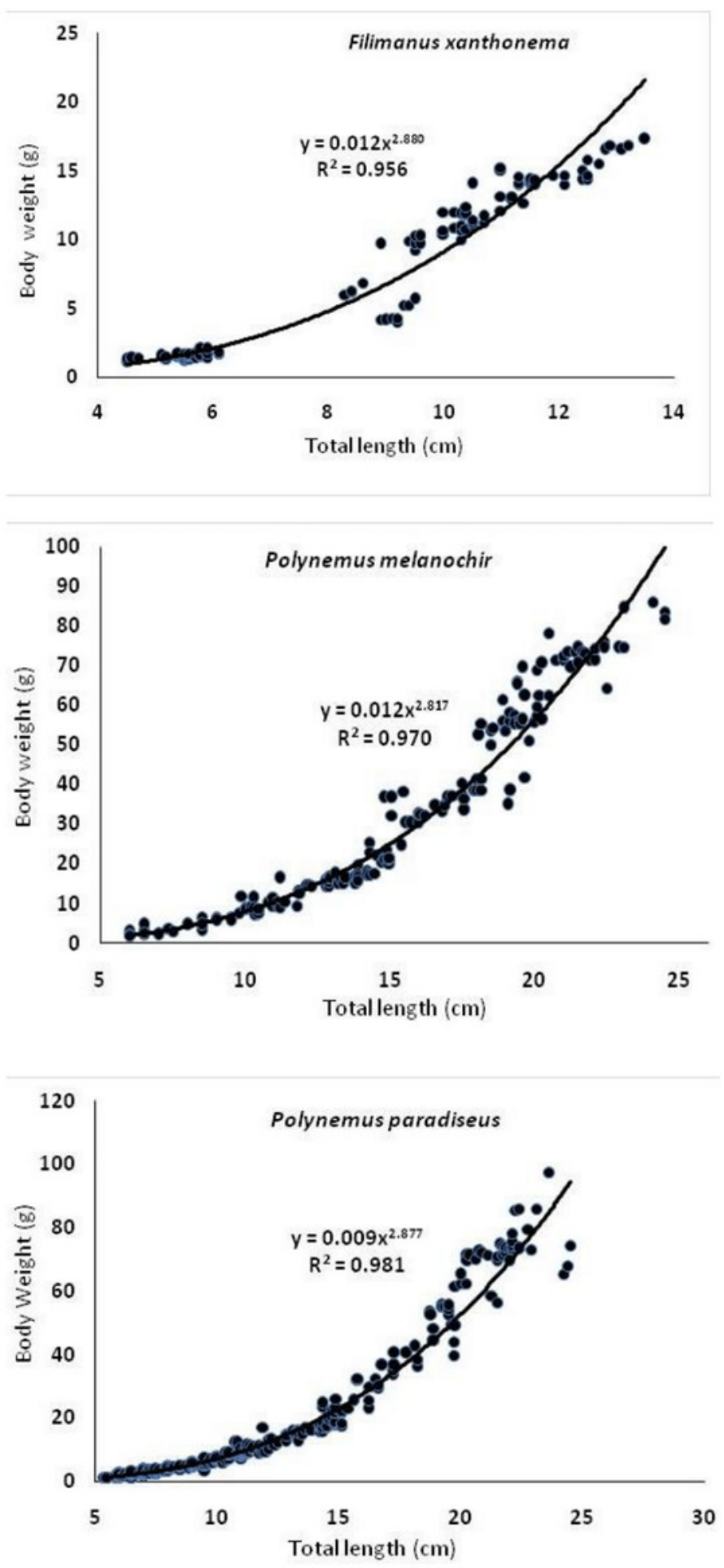

Logarithmic LWRS
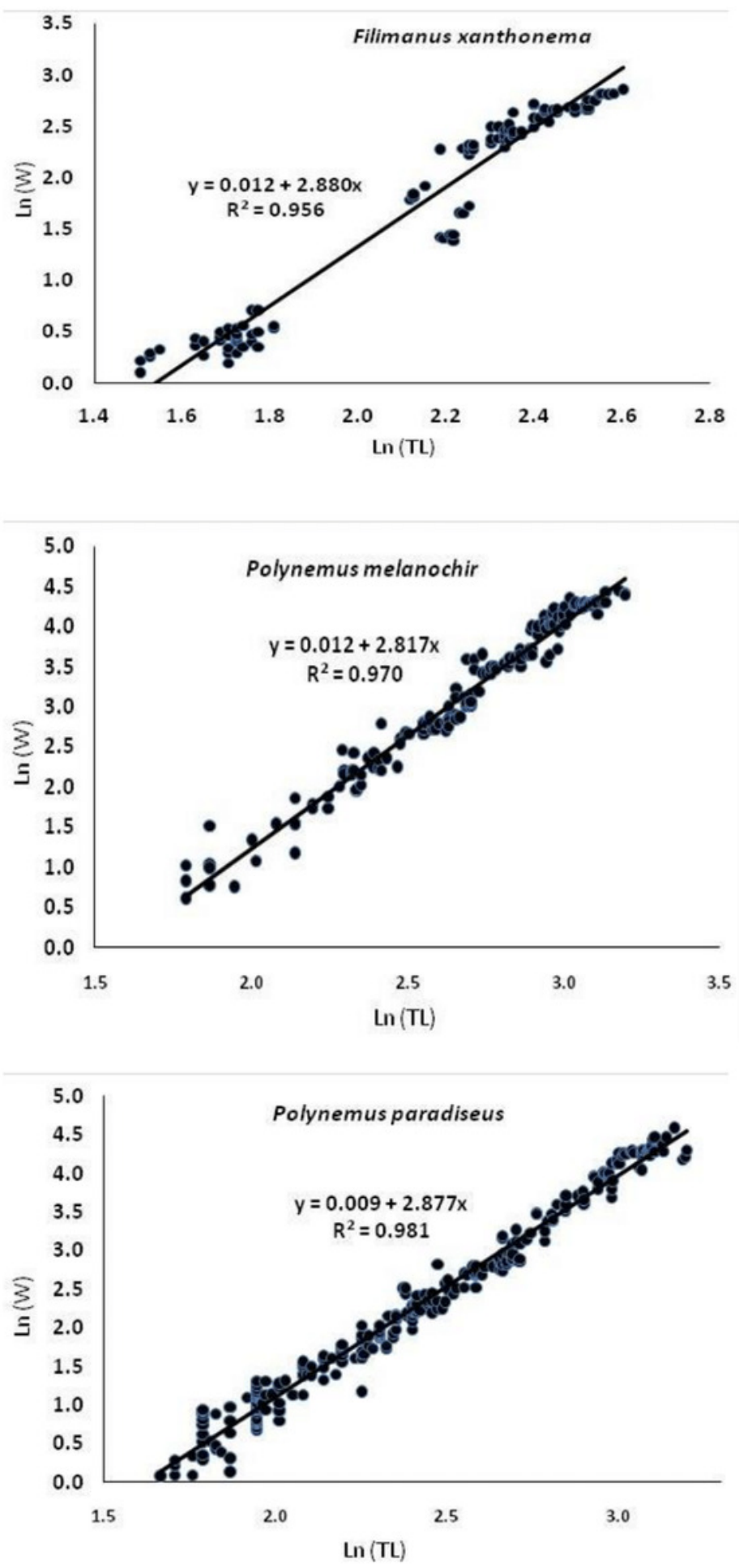


\section{Figure 5}

Categorized body-shape by relative condition factors of three polynemids - Filimanus xanthonema, Polynemus melanochir and Polynemus paradiseus

Higher $\mathrm{Kn}(>1)$ mean fishes are more fatty or rounded and lower $(<1) \mathrm{Kn}$ means fishes are thin or flat while $\mathrm{Kn}=1$ implies proportionate body shape (elaborated in Table 5).

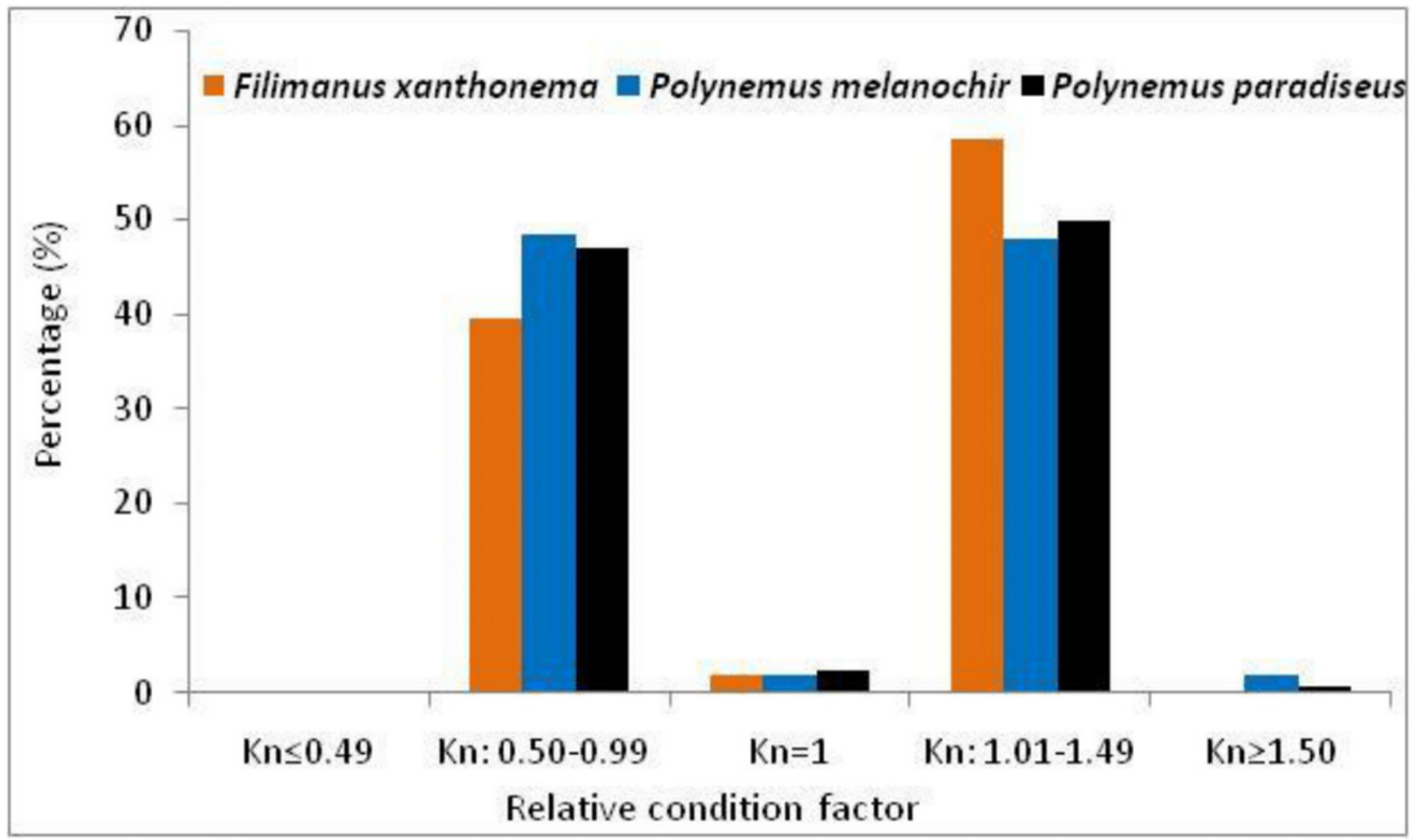




\section{Figure 6}

Growth curves of three polynemids - (A) Filimanus xanthonema (B) Polynemus melanochir and (C) Polynemus paradiseus

Black bars are maximum monthly-based frequencies, white are minimum monthly-based frequencies and blue lines representing growth curves. Month-wise length-frequency distribution data were used to construct this curve (using ELEFAN based FiSAT). 


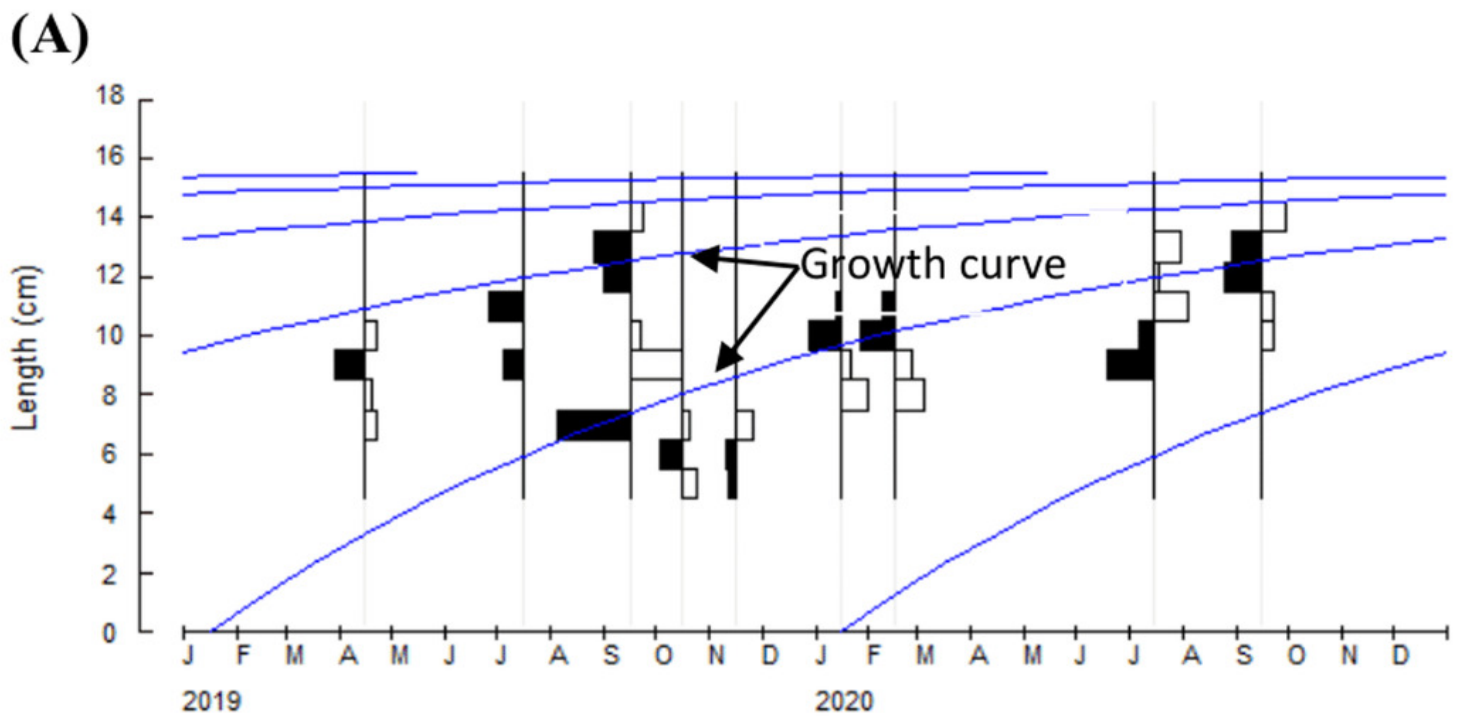

(B)

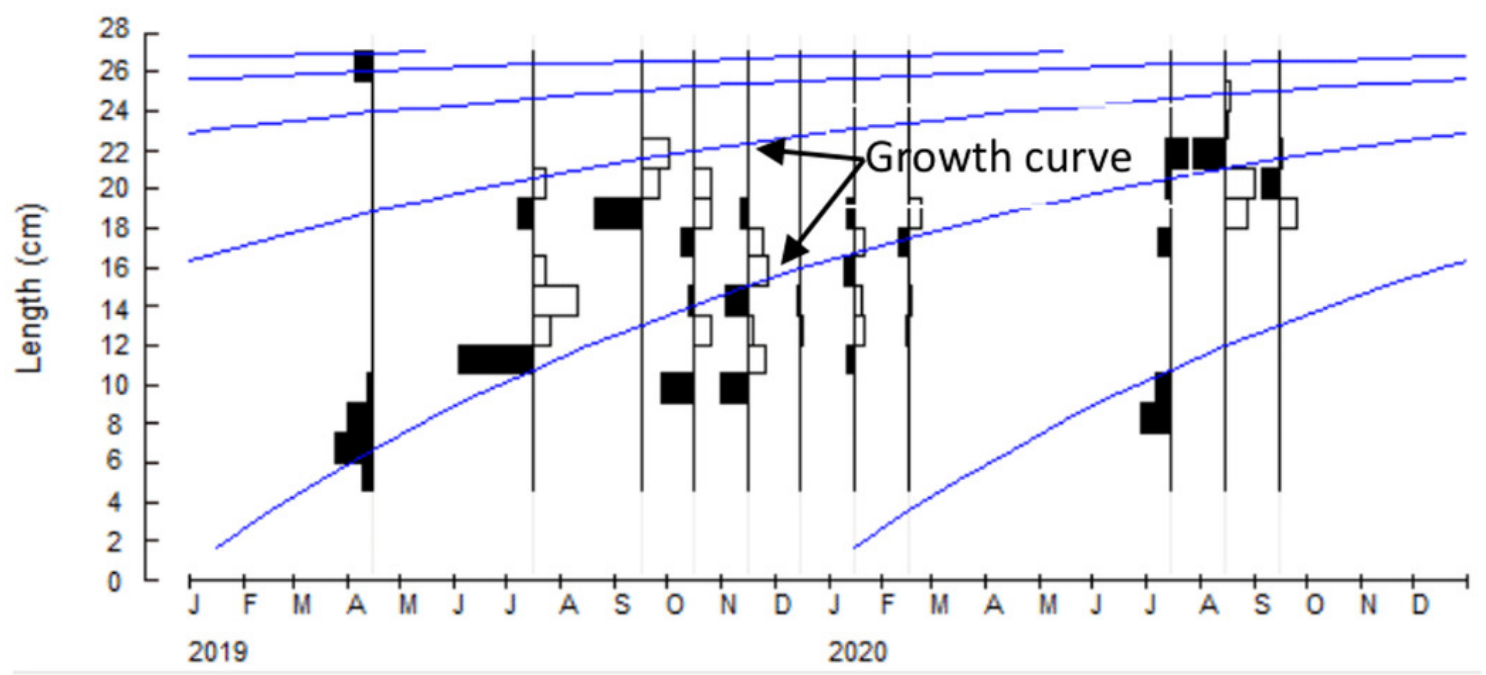

(C)

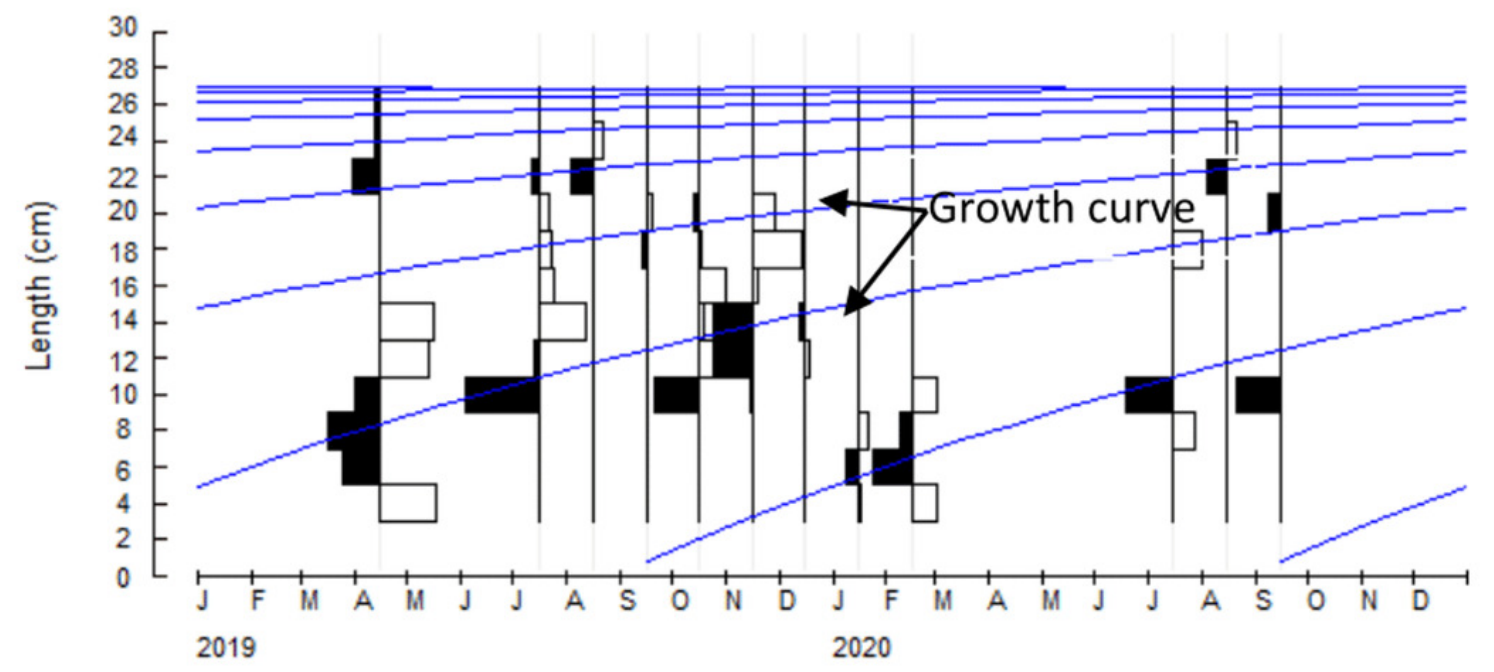


Figure 7

Length converted catch curves of three polynemids - (A) Filimanus xanthonema (B) Polynemus melanochir and (C) Polynemus paradiseus

Yellow and black dots are calculated points. Black dots are used to fit regression line (lengthgroup that are fully recruited into the stock and used in the analysis). Black outlines circles are the extrapolated points to estimate the probability of capture. In $\mathrm{Y}$-axis, $\mathrm{N}=$ number of fish in length class, $d t=$ time needed for the fish to grow (with respect to $t_{0=0}$ ).

(A)

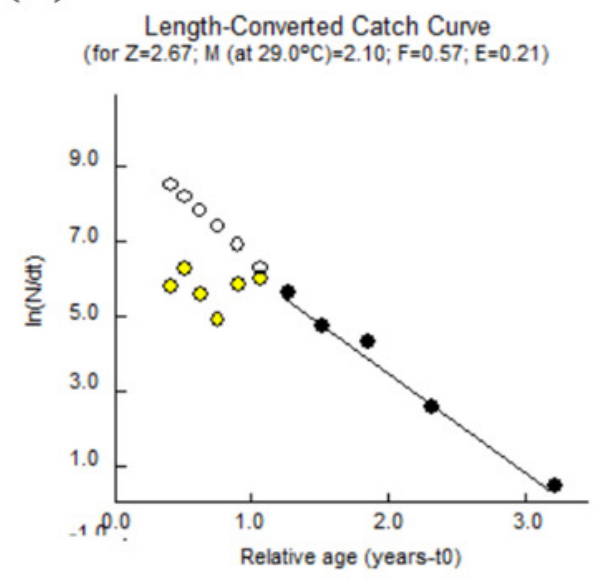

(B)

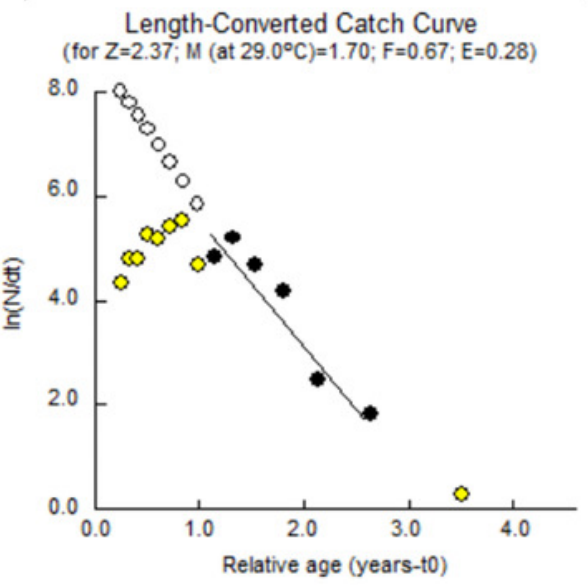

(C)
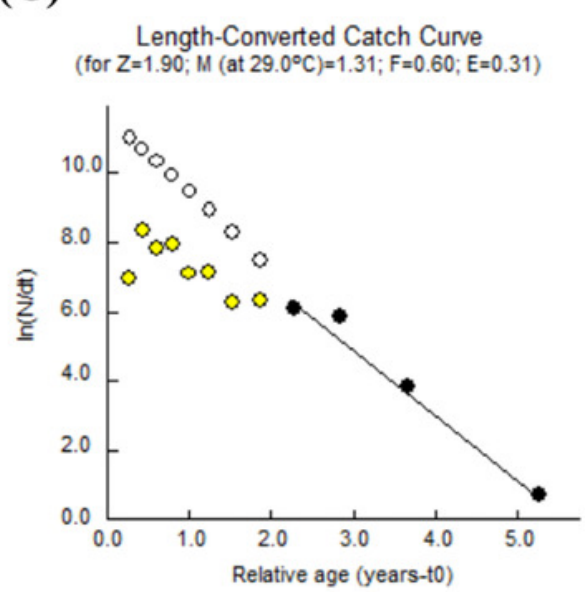
Figure 8

Probability of capture of three polynemids - (A) Filimanus xanthonema (B) Polynemus melanochir (C) Polynemus paradiseus

Probability of capture used to determine gear-specific (here Gnian) selection curves of lengths at $25 \%, 50 \%$ and $75 \%$ catch.

(A)

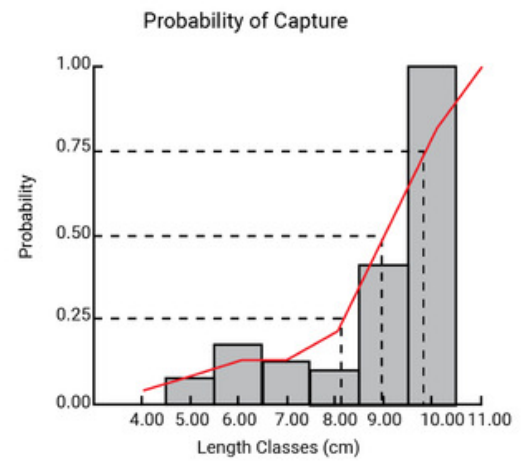

(B)

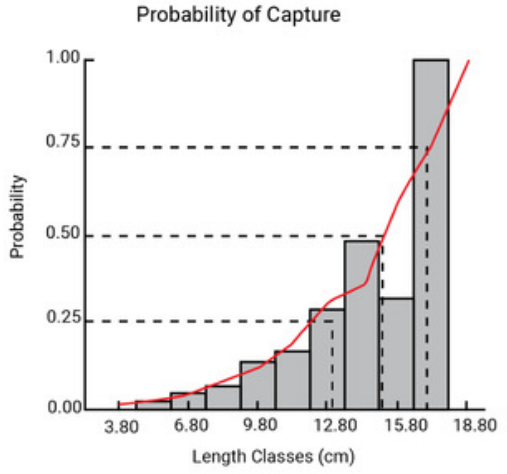

(C)

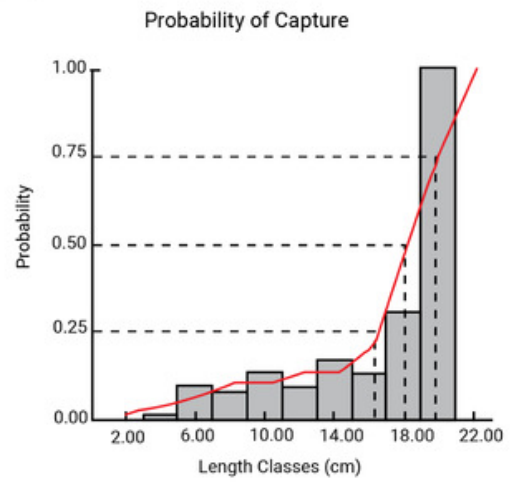


Figure 9

Relative Yield per Recruit and Biomass per Recruit of three polynemids - (A) Filimanus xanthonema (B) Polynemus melanochir and (C) Polynemus paradiseus

Red line represents E-50, green is E-10 and yellow line represents E-max. Black lines are either Yield per Recruit (Y/R), Maximum Sustainable Yield points (MSY) or Biomass per Recruit $(B / R)$. 


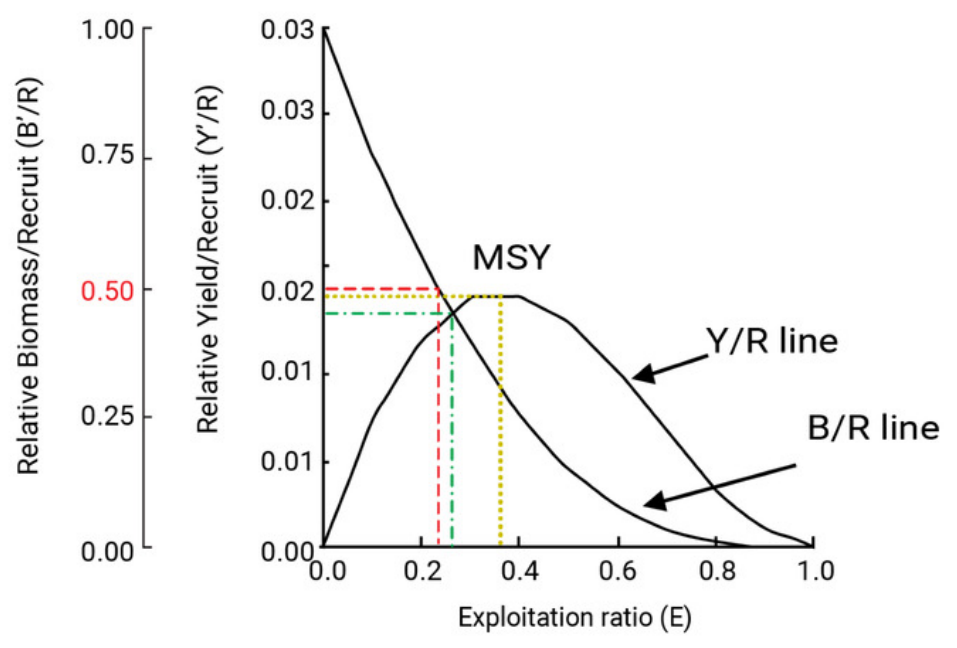

(A)

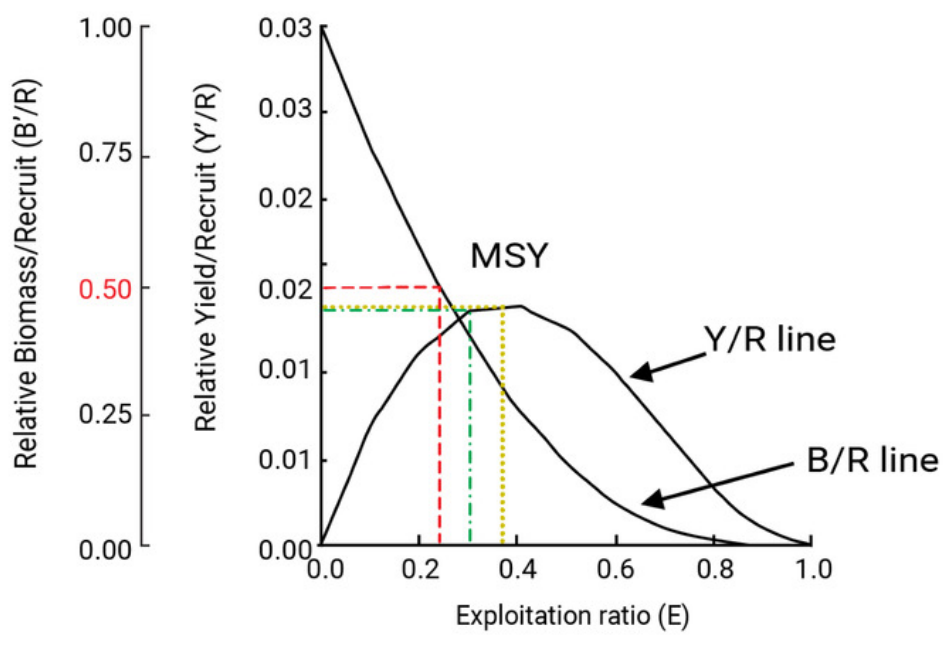

(B)

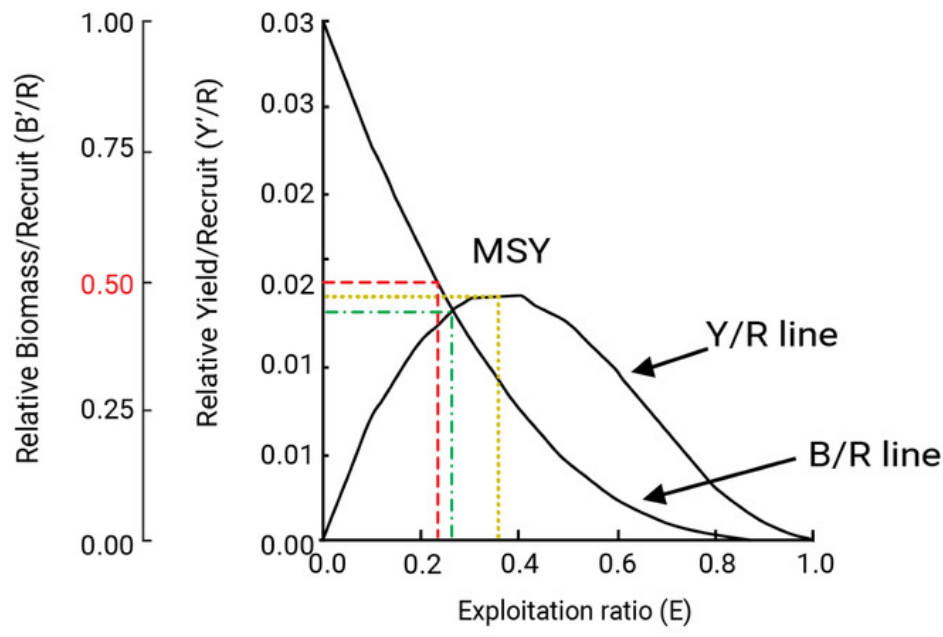

(C) 


\section{Figure 10}

Relative recruitment patterns of three polynemids - (A) Filimanus xanthonema (B) Polynemus melanochir and (C) Polynemus paradiseus

Red line was fitted using Gaussian distribution (normal distribution) curve. Though these fish stock express recruitment throughout the year, relatively single peak in species A while showed double peaks in B and C following Gaussian distribution curve. However, secondary peaks in species $B$ and species $C$ are smaller than primary peaks.

(A)

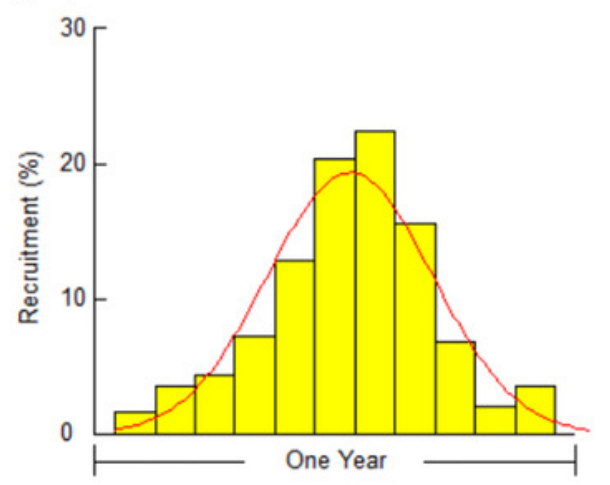

(B)

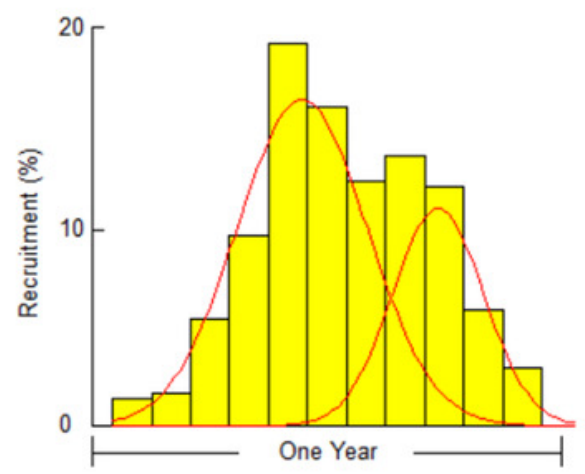

(C)

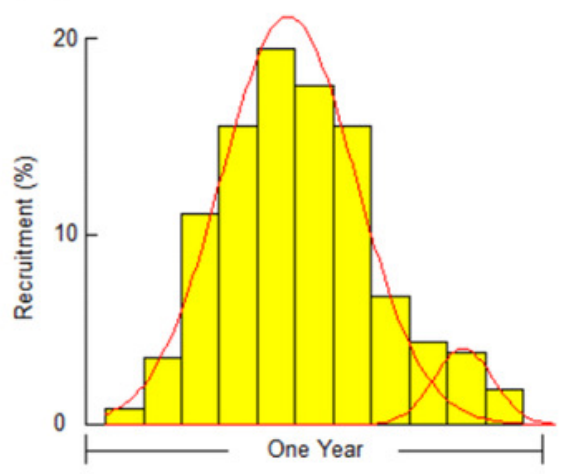




\section{Table $\mathbf{1}$ (on next page)}

Estimation of Length-weight relationships (LWRs) and condition factor (Kn) parameters by other researchers 
1 Table 1 Estimation of Length-weight relationships (LWRs) and condition factor (Kn) parameters

2 by other researchers

\begin{tabular}{|c|c|c|c|c|c|}
\hline \multirow[t]{2}{*}{ Species } & \multirow{2}{*}{$\begin{array}{l}\text { Max } \\
\text { Length } \\
(\mathrm{cm})\end{array}$} & \multicolumn{2}{|l|}{ LWRs } & \multirow{2}{*}{$\begin{array}{l}\text { Condition } \\
\text { factor } \\
(\mathrm{Kn})\end{array}$} & \multirow[t]{2}{*}{ Reference } \\
\hline & & $\bar{a}$ & $b$ & & \\
\hline Filimanus xanthonema & TL 14.00 & & & & Feltes (1991) \\
\hline Polynemus paradeseus & TL 20.00 & 0.0087 & 2.739 & - & Nabi, et al. (2007) \\
\hline Polynemus paradeseus & TL 22.50 & - & $\begin{array}{l}3.39- \\
3.51\end{array}$ & - & Nabi, et al. (1999) \\
\hline Polynemus paradeseus & TL 23.00 & - & & - & Islam et al. (1993) \\
\hline Polynemus paradeseus & TL 17.1 & 0.003 & 3.23 & - & Hossain et al. (2015) \\
\hline Polynemus paradeseus & TL 13.70 & 0.032 & 2.80 & $1.8-2.23$ & $\begin{array}{l}\text { Chaklader et al. } \\
\text { (2016) }\end{array}$ \\
\hline Polynemus paradeseus & TL 21.70 & $\begin{array}{l}0.0061- \\
0.0127\end{array}$ & $\begin{array}{l}2.737- \\
3.035\end{array}$ & $\begin{array}{l}0.867- \\
1.314\end{array}$ & Hossain et al. (2017) \\
\hline Polynemus melanochir & TL 20 & - & - & - & $\begin{array}{l}\text { Motomura and Sabaj } \\
(2002)\end{array}$ \\
\hline Polydactylus plebeius & $\begin{array}{l}\text { Max SL } \\
45\end{array}$ & - & - & - & Motomura (2004) \\
\hline Polydactylus plebeius & $\begin{array}{l}\text { Common } \\
\text { TL } 30\end{array}$ & - & - & - & Sommer, et al. (1996) \\
\hline Polydactylus plebeius & & 0.0114 & 3.057 & & Andina et al. (2020) \\
\hline Polydactylus bifurcus & SL 27 & - & - & - & Motomura (2004) \\
\hline Polydactylus longipes & SL 26 & - & - & - & $\begin{array}{l}\text { Gumanao, et al. } \\
\text { (2016) }\end{array}$ \\
\hline Polynemus aquilonaris & SL 15.8 & - & - & - & Motomura (2003) \\
\hline Polynemus dubius & SL 20 & - & - & - & Rainboth (1996) \\
\hline Polynemus hornadayi & SL 19.5 & - & - & - & Kottelat, et al. (1993) \\
\hline $\begin{array}{l}\text { Polynemus } \\
\text { kapuasensis }\end{array}$ & SL 17 & - & - & - & Motomura (2004) \\
\hline Polyneтus multifilis & SL 28 & - & - & - & Motomura (2004) \\
\hline
\end{tabular}

3 
Table 2 (on next page)

Estimation population dynamics parameters by other researchers 
1 Table 2 Estimation population dynamics parameters by other researchers

\begin{tabular}{|c|c|c|c|c|c|c|c|c|c|}
\hline Species & $\begin{array}{l}\mathrm{L} \infty \\
(\mathrm{cm})\end{array}$ & $\begin{array}{l}\mathrm{K} \\
\left(\mathrm{yr}^{-1}\right)\end{array}$ & $\begin{array}{l}\mathrm{M} \\
\left(\mathrm{yr}^{-1}\right)\end{array}$ & $\begin{array}{l}\mathrm{F} \\
\left(\mathrm{yr}^{-1}\right)\end{array}$ & Lc & E & $\mathrm{E}_{\max }$ & $\begin{array}{l}\text { Study } \\
\text { location }\end{array}$ & Reference \\
\hline P. paradeseus & 20.48 & 0.48 & 1.21 & 3.17 & & 0.72 & 0.356 & $\begin{array}{l}\text { Bangla } \\
\text { desh }\end{array}$ & $\begin{array}{l}\text { Nabi, et al. } \\
\text { (2007) }\end{array}$ \\
\hline P. paradeseus & 21.30 & 0.52 & & & & & & $\begin{array}{l}\text { Bangla } \\
\text { desh }\end{array}$ & $\begin{array}{l}\text { Islam et al. } \\
\text { (1993) }\end{array}$ \\
\hline $\begin{array}{l}\text { Polydactylus } \\
\text { plebeius }\end{array}$ & 51.1 & 0.64 & 1.17 & 1.59 & $\begin{array}{l}30 . \\
21\end{array}$ & 0.58 & & $\begin{array}{l}\text { Indones } \\
\text { ia }\end{array}$ & $\begin{array}{l}\text { Andina et al. } \\
(2020)\end{array}$ \\
\hline $\begin{array}{l}\text { Polynemus } \\
\text { heptadactylus }\end{array}$ & 38.4 & 0.82 & 1.47 & 4.14 & & 0.74 & 0.54 & India & $\begin{array}{l}\text { Prasad et al. } \\
(2005)\end{array}$ \\
\hline
\end{tabular}

2

3 


\section{Table 3(on next page)}

Total length and body weight of three polynemid fishes

*Footnote: Number ( $\left.\mathrm{N}^{*}\right)$ used for population dynamics and $\mathrm{N}$ in parentheses showed number of fish used for LWR analyses after eliminating the outliers according to Froese, 2006. 
1 Table 3 Total length and body weight of three polynemid fishes.

\begin{tabular}{|c|c|c|c|c|c|c|c|}
\hline \multirow{2}{*}{$\begin{array}{l}\text { Family: } \\
\text { Polynemidae: } \\
\text { Species name }\end{array}$} & \multirow[t]{2}{*}{$\mathrm{N}^{*}$} & \multicolumn{2}{|c|}{$\begin{array}{l}\text { Total length } \\
(\mathrm{cm})\end{array}$} & \multicolumn{2}{|c|}{$\begin{array}{c}\text { Body Weight } \\
(\mathrm{g})\end{array}$} & \multirow{2}{*}{$\begin{array}{l}\text { Predicted } \\
\text { Extreme } \\
\text { Length } \\
(\mathrm{cm})\end{array}$} & \multirow{2}{*}{$\begin{array}{l}95 \% \mathrm{CI} \\
\text { Extreme } \\
\text { Length } \\
\text { ranges }(\mathrm{cm})\end{array}$} \\
\hline & & Min & Max & Min & Max & & \\
\hline $\begin{array}{l}\text { Filimanus } \\
\text { xanthonema }\end{array}$ & $\begin{array}{c}152 \\
(111)\end{array}$ & 4.50 & 13.50 & 1.10 & 17.30 & 16.22 & $13.57-18.87$ \\
\hline $\begin{array}{l}\text { Polynemus } \\
\text { melanochir }\end{array}$ & $\begin{array}{c}254 \\
(165)\end{array}$ & 4.50 & 26.00 & 1.12 & 86.00 & 26.71 & $23.89-29.53$ \\
\hline $\begin{array}{l}\text { Polynemus } \\
\text { paradiseus }\end{array}$ & $\begin{array}{c}459 \\
(303)\end{array}$ & 3.60 & 31.50 & 0.37 & 106.68 & 31.88 & $25.11-35.05$ \\
\hline
\end{tabular}

2 *Footnote: Number $\left(\mathrm{N}^{*}\right)$ used for population dynamics and $\mathrm{N}$ in parentheses showed number of 3 fish used for LWR analyses after eliminating the outliers according to Froese, 2006. 


\section{Table 4(on next page)}

LWR parameters with some descriptive statistics obtained for three polynemid fish species from Batang Lassa Estuary, East Malaysia

Note: $\mathrm{N}=$ sample size; $\mathrm{Min}=$ minimum; $\mathrm{Max}=$ maximum; $a=$ intercept, $b=$ slope of the regression curve; $\mathrm{CL}=$ confidence limits, $\mathrm{A}(-)=$ negative allometry; $R^{2}=$ coefficient determination 
1 Table 4 LWR parameters with some descriptive statistics obtained for three polynemid fish

2 species from Batang Lassa Estuary, East Malaysia

\begin{tabular}{|c|c|c|c|c|c|c|c|}
\hline \multirow[t]{2}{*}{$\begin{array}{l}\text { Family: Polynemidae: } \\
\text { Species name }\end{array}$} & \multirow[t]{2}{*}{$\mathrm{N}$} & \multicolumn{2}{|c|}{$\begin{array}{l}\text { Regression } \\
\text { parameters }\end{array}$} & \multirow[t]{2}{*}{$95 \%$ CI $a$} & \multirow[t]{2}{*}{$95 \%$ CI $b$} & \multirow[t]{2}{*}{$R^{2}$} & \multirow[t]{2}{*}{$\begin{array}{l}\text { Growth } \\
\text { pattern }\end{array}$} \\
\hline & & $a$ & $b$ & & & & \\
\hline Filimanus xanthonema & 111 & 0.012 & 2.88 & $0.0098-0.0143$ & $2.801-3.014$ & 0.956 & $\mathrm{~A}(-)$ \\
\hline Polynemus melanochir & 165 & 0.012 & 2.82 & $0.0113-0.0136$ & $2.748-2.951$ & 0.970 & $\mathrm{~A}(-)$ \\
\hline Polynemus paradiseus & 303 & 0.009 & 2.87 & $0.0086-0.0117$ & $2.692-2.993$ & 0.981 & $\mathrm{~A}(-)$ \\
\hline
\end{tabular}

3 Note: N=sample size; Min=minimum; Max=maximum; $a=$ intercept, $b=$ slope of the regression

4 curve; $\mathrm{CL}=$ confidence limits, $\mathrm{A}(-)=$ negative allometry; $R^{2}=$ coefficient determination. 


\section{Table 5 (on next page)}

Relative condition factor and body shape types of three polynemid fishes

Footnote: $\mathrm{N}=$ number of fishes, $\mathrm{Kn}=$ relative condition factor 
1 Table 5 Relative condition factor and body shape types of three polynemid fishes

\begin{tabular}{|c|c|c|c|c|}
\hline Species & & Frequency & & Inference on Body \\
\hline$(\mathrm{N})$ & $\mathrm{Kn}$ & $(\mathrm{N})$ & Percentage (\%) & Shape Expression \\
\hline Filimanus xanthonema & $<=0.49$ & 0 & 0.00 & Very flat/thin \\
\hline$(\mathrm{N}=111)$ & $0.50-0.99$ & 44 & 39.64 & Flat/thin \\
\hline & 1 & 2 & 1.80 & Proportional \\
\hline & $1.01-1.49$ & 65 & 58.56 & Rounded/fat \\
\hline & $>=1.50$ & 0 & 0.00 & Very rounded/fat \\
\hline & Min $=0.56$ & & & Flat/thin \\
\hline & $\operatorname{Max}=1.48$ & & & Rounded/fat \\
\hline & Mean \pm SD & $=1.02 \pm 0.19$ & & Around proportional \\
\hline Polynemus melanochir & $<=0.49$ & 0 & 0.00 & Very flat/thin \\
\hline$(\mathrm{N}=165)$ & $0.50-0.99$ & 79 & 48.47 & Flat/thin \\
\hline & 1 & 3 & 1.84 & Proportional \\
\hline & $1.01-1.49$ & 78 & 47.85 & Rounded/fat \\
\hline & $>=1.50$ & 3 & 1.84 & Very rounded/fat \\
\hline & $\operatorname{Min}=0.63$ & & & Flat/thin \\
\hline & $\mathrm{Max}=2.46$ & & & Very rounded/fat \\
\hline & Mean \pm SD & $1.02 \pm 0.18$ & & Around proportional \\
\hline Polynemus paradeseus & $<=0.49$ & 0 & 0.00 & Very flat/thin \\
\hline$(\mathrm{N}=303)$ & $0.50-0.99$ & 134 & 47.02 & Flat/thin \\
\hline & 1 & 7 & 2.46 & Proportional \\
\hline & $1.01-1.49$ & 142 & 49.82 & Rounded/fat \\
\hline & $>=1.50$ & 2 & 0.70 & Very rounded/fat \\
\hline & $\operatorname{Min}=0.52$ & & & Flat/thin \\
\hline & $\operatorname{Max}=1.93$ & & & Very rounded/fat \\
\hline & Mean \pm SD & $1.01 \pm 0.17$ & & Around proportional \\
\hline
\end{tabular}

2 Footnote: $\mathrm{N}=$ number of fishes, $\mathrm{Kn}=$ relative condition factor 


\section{Table 6(on next page)}

Growth parameters, mortality parameters, and exploitation rates for three polynemid fishes

Footnote: $L_{\infty}(\mathrm{cm})=$ asymptotic length; $K=$ growth coefficient; $\phi^{\prime}=$ growth performance index; $\mathrm{M}=$ natural mortality, $\mathrm{F}=$ fishing mortality, $\mathrm{Z}=$ total mortality; $\mathrm{E}=$ exploitation rates, $E_{\max }=$ maximum exploitation rate, $\mathrm{LC}=$ length at first capture 
1 Table 6 Growth parameters, mortality parameters, and exploitation rates for three polynemid

2 fishes.

\begin{tabular}{|c|c|c|c|c|c|c|c|c|c|c|}
\hline \multirow{2}{*}{$\begin{array}{l}\text { Species } \\
\text { Name }\end{array}$} & \multicolumn{3}{|c|}{ Growth Parameters } & \multicolumn{3}{|c|}{ Mortality } & \multicolumn{2}{|c|}{ Exploitation } & \multirow[t]{2}{*}{$\mathrm{Lc}$} & \multirow[t]{2}{*}{ Age } \\
\hline & $\begin{array}{l}\mathrm{L} \infty \\
(\mathrm{cm})\end{array}$ & $\begin{array}{l}\mathrm{K} \\
\left(\mathrm{yr}^{-1}\right)\end{array}$ & $\phi '$ & $\mathrm{M}$ & $\mathrm{F}$ & $\mathrm{Z}$ & $\mathrm{E}$ & $\mathrm{E}_{\max }$ & & \\
\hline $\begin{array}{l}\text { Filimanus } \\
\text { xanthonema }\end{array}$ & 15.75 & 0.95 & 2.37 & 2.10 & 0.57 & 2.67 & 0.21 & 0.361 & 5.0 & 3.1 \\
\hline $\begin{array}{l}\text { Polynemus } \\
\text { melanochir }\end{array}$ & 27.61 & 0.87 & 2.82 & 1.69 & 0.67 & 2.37 & 0.28 & 0.369 & 3.8 & 3.5 \\
\hline $\begin{array}{l}\text { Polynemus } \\
\text { paradeseus }\end{array}$ & 27.30 & 0.58 & 2.64 & 1.30 & 0.60 & 1.90 & 0.31 & 0.361 & 4.0 & 5.1 \\
\hline
\end{tabular}

3 Footnote: $\mathrm{L} \infty(\mathrm{cm})=$ asymptotic length; $\mathrm{K}=$ growth coefficient; $\phi$ '= growth performance index;

$4 \mathrm{M}=$ natural mortality, $\mathrm{F}=$ fishing mortality, $\mathrm{Z}=$ total mortality; $\mathrm{E}=$ exploitation rates,

$5 \quad E_{\max }=$ maximum exploitation rate, $\mathrm{Lc}=$ length at first capture. 